\title{
EL CASO AVENA Y OTROS NACIONALES MEXICANOS (MÉXICO C. ESTADOS UNIDOS DE AMÉRICA) ANTE LA CORTE INTERNACIONAL DE JUSTICIA
}

\author{
Juan Manuel GóMEZ-RoBLEDo V.*
}

RESUMEN: Este trabajo se refiere al fallo en el caso Avena y otros nacionales mexicanos (México c. Estados Unidos) dictado el 31 de marzo de 2004, por la Corte Internacional de Justicia, que pone fin a un litigio que inició el gobierno de México el 9 de enero de 2003. Este fallo, "definitivo e inapelable", resuelve una controversia sobre la aplicación y la interpretación de la Convención de Viena sobre Relaciones Consulares de 1963, tratado del que México y Estados Unidos de América son parte. De su resolución depende la suerte de cientos de mexicanos que son arrestados en los Estados Unidos de América por la presunta comisión de delitos graves, sin tener acceso a la protección consular de su país de origen, y pueden ser condenados a penas severas, incluso a la pena de muerte, en violación de las garantías del debido proceso legal.

ABSTRACT: This work is about the Case Avena and other Mexican Nationals (Mexico vs. United States) pronounced on March 31, 2004 by the International Court of Justice concluding the judgment the Mexican Government began the 9th. of January 2003. This "definitive and final" sentence solves a controversy on the application and interpretation of the 1963 Vienna Convention on Consular Relations, treaty which both Mexico and the USA are Parties. The solution of this case was decisive for the fate of thousands of Mexicans that are arrested in the US for committing assumed crimes, without having access to the consular protection of their home country and could be condemned to severe punishment, including death penalty, violating the bridge of the due legal process.

RÉSUMÉ: Cet article s'agit sur le Cas Avena et d'autres nationals Mexicains (Mexique versus États-Unis) qui a eté prononcé en Mars le 31, 2004 par la Cour International de Justice en arrivant au fin du jugement que le Gouvernement Mexicain a commencé le Janvier 9, 2003. Ce sentence "définitive et inappelable" donne une solution pour l'application et interpretation de la Convention de Vienne des Relations Consulaires de 1963, même de laquelle le Mexique et les États Unies sont parties. La solution de ce cas est décisive pour miles des Mexicains qui sont arrêtés aux États-Unis pour la supposé commission des crimes sans avoir accès direct à la protection consulaire de leur pays d'origine et avec la possibilité d'être condamnés a peines sévères, comme la peine de mort, en violation des garanties du processus légal dû.

* Representante permanente adjunto de México ante la ONU. 
A la memoria de mi Padre, toto corde

SUMARIO: I. Antecedentes. II. Los argumentos de México. III. Los argumentos de los Estados Unidos de América. IV. Las decisiones de la corte. V. El fallo Avena ante la prueba de los hechos.

\section{ANTECEDENTES}

El 31 de marzo de 2004, la Corte Internacional de Justicia, el órgano judicial principal de las Naciones Unidas, rindió su fallo en el caso Avena y otros nacionales mexicanos (México c. Estados Unidos), poniendo fin a un litigio que inició el gobierno de México el 9 de enero de 2003.

Este fallo, "definitivo e inapelable", ${ }^{1}$ resuelve con base en el derecho internacional una controversia sobre la aplicación y la interpretación de la Convención de Viena sobre Relaciones Consulares de 1963 (en adelante la Convención de Viena), tratado del que México y Estados Unidos de América son parte. No se trataba de una controversia menor. En efecto, de su resolución depende la suerte de cientos de mexicanos que son arrestados en los Estados Unidos de América, por la presunta comisión de delitos graves, sin tener acceso a la protección consular de su país de origen y pueden ser condenados a penas severas, incluso a la pena de muerte, en violación de las garantías del debido proceso legal.

Cuando México tomó la decisión de demandar a Estados Unidos de América ante el máximo tribunal internacional, $54^{2}$ mexicanos estaban condenados a la pena de muerte y $4^{3}$ habían sido ejecutados en circunstancias en las que sus derechos a la protección consular habían sido violados.

1 Artículo 60 del Estatuto de la Corte Internacional de Justicia que "forma parte integrante" de la Carta de las Naciones Unidas, conforme con lo establecido en el artículo 92 de esta última.

2 El número de los nacionales mexicanos amparados por la demanda de México ante la Corte Internacional de Justicia fue modificándose para quedar, al momento de los alegatos orales sobre el fondo, en 52. Estas modificaciones resultaron de haber retirado dos casos (Enrique Zambrano Garibi y Pedro Hernández Alberto), cuando la investigación, en el momento de analizar la Contramemoria de los Estados Unidos, reveló que el primero posee la doble nacionalidad y no puede por ende acogerse a los beneficios del artículo 36 de la Convención de Viena sobre Relaciones Consulares, y el segundo había recibido asistencia consular antes de su interrogatorio.

3 Los dos últimos fueron Javier Suárez Medina el 14 de agosto de 2002 y Miguel Ángel Flores Muñoz el 8 de noviembre de 2000, ambos en Texas. 
¿Cómo llegó el gobierno de México a la decisión de iniciar un litigio ante el máximo tribunal internacional, por primera vez en la historia del país, en contra de Estados Unidos de América? ¿Por qué ahora? ¿Qué opciones jurídicas existían?

¿Qué valor agregado proporciona a la labor de defensa de los derechos humanos de los migrantes mexicanos el fallo de la Corte Internacional de Justicia?

¿Qué garantía existe de que Estados Unidos de América cumpla con las obligaciones que se derivan del fallo?

La defensa de los derechos de los mexicanos que han tenido que emigrar en busca de las oportunidades que su país no les da es, sin duda, la expresión más palpable de nuestra falta de desarrollo, pero acaso el capítulo más honroso del quehacer internacional de México. La historia del servicio exterior mexicano es, en gran medida, la historia de la defensa de nuestros connacionales que, allende la frontera, enfrentan un mundo de barreras culturales, malos tratos y explotación, no exentos de prejuicios raciales, que los colocan en situación de enorme vulnerabilidad ante las autoridades del país de destino.

La labor de protección consular que, por mandato de ley, ${ }_{4}^{4}$ llevan a cabo, día tras día, los cónsules de México, se propone compensar esta desigualdad de facto, mediante la prestación de un sinnúmero de servicios a favor del mexicano en el extranjero, con pleno respeto a las leyes del país de destino. La defensa de quienes enfrentan una pena por definición irreversible, como es la pena capital, ha estado desde siempre en el centro de las preocupaciones del gobierno de México, el cual ha buscado en el derecho internacional más y mejores mecanismos de promoción de los derechos de sus nacionales.

El artículo 36 de la Convención de Viena, en su párrafo primero, ${ }^{5}$ establece la prerrogativa de todos los detenidos extranjeros a ser informa-

4 Ley del Servicio Exterior Mexicano (publicada en el Diario Oficial de la Federación el 4 de enero de 1994 y con reformas publicadas el 25 de enero de 2002) y su reglamento (publicado en el Diario Oficial de la Federación del 23 de agosto de 2002). Para un estudio más completo de esta labor, véase el excelente artículo de Uribe, Víctor Manuel, "Consuls at Work: Universal Instruments of Human Rights and Consular Protection in the Context of Criminal Justice", Houston Journal of International Law, vol. 19, 1997, p. 375. Se recomienda también la lectura del alegato oral del maestro Víctor Manuel Uribe ante la CIJ el 15 de diciembre de 2003, "Avena and other Mexican Nationals (Mexico v. United States of America)", ICJ Reports 2004, http://www.icj-cij.org/.

5 "Con el fin de facilitar el ejercicio de las funciones consulares relacionadas con los nacionales del Estado que envía: a) Los funcionarios consulares podrán comunicarse libremente con 
dos, al momento de su detención, de su derecho a la protección y asistencia consulares.

Como lo sostuvo la Corte Interamericana de Derechos Humanos en la opinión consultiva OC-16/99, promovida por nuestro país, la violación del derecho a la notificación consular en casos de pena capital puede tener graves consecuencias para los derechos fundamentales de los acusados, incluidos el derecho a un juicio justo y a una defensa adecuada. ${ }^{6}$

A partir de junio de 2001, cuando la Corte Internacional de Justicia (en adelante la CIJ) emitió su decisión en el caso LaGrand (Alemania c. Estados Unidos), ${ }^{7}$ México buscó por todos los medios diplomáticos a su alcance convencer a Estados Unidos de América de la necesidad de revisar, por la vía judicial, los casos de mexicanos condenados a la pena de muerte en los que se hubiese acreditado una violación a los derechos de información y notificación consulares, garantizados en el artículo 36 de la Convención de Viena.

Estados Unidos de América, sin embargo, limitó su interpretación del fallo LaGrand a la revisión de las penas impuestas exclusivamente a

los nacionales del Estado que envía y visitarlos. Los nacionales del Estado que envía deberán tener la misma libertad de comunicarse con los funcionarios consulares de ese Estado y de visitarlos; $b$ ) $\mathrm{Si}$ el interesado lo solicita, las autoridades competentes del Estado receptor deberán informar sin retraso alguno a la oficina consular competente en ese Estado cuando, en su circunscripción, un nacional del Estado que envía sea arrestado de cualquier forma, detenido o puesto en prisión preventiva. Cualquier comunicación dirigida a la oficina consular por la persona arrestada, detenida o puesta en prisión preventiva le será asimismo transmitida sin demora por dichas autoridades, las cuales habrán de informar sin dilación a la persona interesada acerca de los derechos que se le reconocen en este apartado; c) Los funcionarios consulares tendrán derecho a visitar al nacional del Estado que envía que se halle arrestado, detenido o puesto en prisión preventiva, a conversar con él y a organizar su defensa ante los tribunales. Asimismo tendrán derecho a visitar a todo nacional del Estado que envía, que en su circunscripción se halle arrestado, detenido o preso en cumplimiento de una sentencia. Sin embargo, los funcionarios consulares se abstendrán de intervenir a favor del nacional detenido, cuando éste se oponga expresamente a ello".

6 Corte Interamericana de Derechos Humanos, El derecho a la información sobre la asistencia consular en el marco de las garantías del debido proceso legal, Opinión consultiva 16/99 del 1o. de octubre de 1999, serie A, número 16 (1999).

7 Para una cabal comprensión del caso Avena, se recomienda leer el fallo de la CIJ en el caso LaGrand, contencioso similar al nuestro y que, en más de un sentido, sentó el precedente sobre el cual México buscaría desarrollar la interpretación del derecho internacional. LaGrand (Germany $v$. United States of America), Judgment of 27 June 2001, ICJ Report 2001, http://www.icj-cij.org/. Otro antecedente importante, por lo menos en cuanto se refiere a la fase de medidas provisionales, es el llamado caso Breard que opuso en la CIJ a Paraguay y a Estados Unidos de América en un asunto semejante a los casos LaGrand y Avena; este caso no llegó a la etapa de fondo, al haber retirado Paraguay la demanda luego de que Estados Unidos de América ejecutó al nacional paraguayo Angel Breard. Sobre el particular, véase Vienna Convention on Consular Relations (Paraguay v.United States of America), ICJ Report 1998, http://www.icj-cij.org/. 
través de los mecanismos de clemencia ejecutiva ${ }^{8}$ en vista de la libertad de medios que le señaló la CIJ para dar cumplimiento a la obligación de reparar la violación del artículo 36. Como veremos, México argumentaría que el mecanismo de clemencia ejecutiva en modo alguno puede ser considerado como satisfaciendo a los requisitos del fallo LaGrand y, por consiguiente, no puede constituir reparación en derecho internacional de la violación de las obligaciones del artículo 36.

El caso de Gerardo Valdez Maltos es paradigmático del tipo de violaciones de que son objeto nuestros compatriotas por parte de las autoridades federales y locales de los Estados Unidos de América.

El gobierno de México se enteró de la situación del señor Valdez en abril de 2001, tan sólo tres meses antes de su fecha de ejecución, de manera casi fortuita, es decir sin que el connacional hubiese recibido asistencia consular durante los once años que llevaba recluido enfrentando el juicio por homicidio. Gracias a la intervención del Programa de Asistencia Jurídica para Mexicanos que enfrentan la Pena de Muerte a cargo de la Consultoría Jurídica de la cancillería, de inmediato se contrató a experimentados abogados en litigio capital, así como a investigadores y a expertos psiquiatras y neuropsicólogos, quienes, en un lapso sumamente breve, obtuvieron y presentaron una serie de elementos mitigantes de la responsabilidad del señor Valdez en el homicidio de que se le acusaba.

Durante el segundo semestre de 2001, el caso fue objeto de numerosas gestiones del gobierno mexicano, en las que destaca la intervención directa del presidente de la república, Vicente Fox, para obtener la gracia del gobernador luego de que la Junta Local de Perdones y Libertad Condicional recomendara la conmutación de la pena por la cadena perpetua, en atención a los argumentos de México. En este contexto, se obtuvieron, primero, dos prórrogas a su ejecución y, meses después, la Corte de Ape-

8 En LaGrand, la CIJ estableció la obligación general de reparar una violación de las obligaciones derivadas del artículo 36 de la Convención de Viena en los siguientes términos: "La corte considera al respecto, que si los Estados Unidos, pese a su compromiso [de asegurar la implementación de medidas específicas adoptadas en cumplimiento de sus obligaciones conforme al artículo 36, párrafo 1(b)], faltaren a su obligación de notificación consular en detrimento de nacionales alemanes, una disculpa no sería suficiente en casos en que los individuos involucrados hayan quedado sujetos a detención prolongada o hayan sido sentenciados a penas graves. En caso de tal condena, los Estados Unidos deberían permitir la revisión y reconsideración del veredicto de culpabilidad y de la pena, tomando en cuenta la violación de los derechos previstos en la convención. Esta obligación puede cumplirse en varias formas. La elección de los medios debe dejarse a los Estados Unidos" (trad del autor), Ibidem, pp. 513 y 514, párr. 125. 
laciones Criminales de Oklahoma, en una decisión sin precedentes, decidió anular la imposición de la pena de muerte y ordenó que una corte de distrito celebrase una nueva audiencia para reconsiderar la pena.

En su decisión, la Corte de Apelaciones reconoció, en forma expresa, el papel fundamental que el gobierno de México desempeñó en la obtención de evidencia inédita sobre la historia familiar y el estado mental del acusado, las cuales no fueron consideradas, en su momento, por el jurado que lo sentenció a muerte en 1990, debido a la notoria incompetencia de su defensor de oficio.

Las anteriores circunstancias, aunadas a los elementos allegados por el gobierno de México sobre la asistencia que el consulado mexicano hubiera prestado a favor del acusado, llevaron al tribunal de apelaciones a concluir que, de haber sido notificado oportunamente del caso, el gobierno de nuestro país habría intervenido para asegurarse de que el connacional contara con una defensa adecuada y un juicio justo.

Asimismo, la Corte de Apelaciones - tal y como lo argumentó en todo momento el gobierno de México - sostuvo que las autoridades de Oklahoma, que tuvieron contacto con el connacional mucho antes del juicio y tenían pleno conocimiento de su nacionalidad mexicana, incumplieron con su obligación de notificarle acerca de su derecho a comunicarse con el consulado mexicano.

Con base en estos argumentos y en el hecho de que el jurado no tuvo a su alcance la evidencia mitigante fundamental que el gobierno de México contribuyó a descubrir, el tribunal concluyó que era razonablemente probable que, de haberla conocido, el jurado no lo habría sentenciado a la pena máxima.

Más adelante, una corte de distrito resolvería en definitiva, al condenar a Gerardo Valdez a la prisión de por vida.

No obstante este logro, que no dejaba de ser una excepción, la experiencia posterior probaría que el gobierno federal de los Estados Unidos de América no estaba dispuesto a intervenir más allá de los mecanismos de clemencia para obtener la revisión de los casos en los que se hubiere acreditado la violación del artículo 36.

En efecto, en agosto de 2002, fue ejecutado en Texas Javier Suárez Medina, al cabo de múltiples intentos de México por conseguir por lo menos una prórroga a su ejecución, para dar tiempo de que se considerasen las violaciones del artículo 36. Una prueba tangible del desacuerdo del gobierno de México ante esta ejecución fue la cancelación del viaje 
del presidente Vicente Fox a Texas en dónde debía reunirse con el presidente George W. Bush, además del gobernador del Estado, Rick Perry.

Si no se acudió a la CIJ en este caso, fue porque el Tribunal de La Haya había dejado en claro en el caso LaGrand que "una buena administración de la justicia exige que una solicitud de medidas provisionales fundada en el artículo 73 del Reglamento de la Corte sea presentada en tiempo oportuno".

Esto significaba que la CIJ no admitiría fácilmente en lo sucesivo la presentación de demandas como éstas, faltando horas o días para la ejecución de la persona, como ocurrió en el caso LaGrand. De ahí que se llegara a la conclusión de que debía acudirse a la corte cuando fuera inminente una ejecución, pero antes de que se fijara fecha para ello y dando oportunidad para que la otra parte presentara sus argumentos. ${ }^{10}$ En el caso LaGrand, la corte se vio en la necesidad de indicar las medidas provisionales sin que mediara audiencia, lo que fue duramente criticado por Estados Unidos de América.

El 16 de diciembre de 2002, en mi carácter de consultor jurídico de la Secretaría de Relaciones Exteriores, me reuní en Washington con el consultor jurídico del Departamento de Estado, el señor William Taft IV, con el objeto de dejar constancia de la existencia de puntos de vista irreconciliables entre los dos países respecto del alcance de los derechos consagrados en la Convención de Viena y respecto de la interpretación que debía darse al fallo LaGrand. Esta última démarche diplomatique tenía más que un valor político: era de gran importancia desde el punto de vista jurídico, con el fin de evitar que Estados Unidos de América argumentara que México no había agotado la vía de la negociación antes de acudir a la corte. En efecto, al término de una larga reunión en la que se abordaron muchos de los aspectos relacionados con el cumplimiento de la obligación de información y notificación consulares, el gobierno de México expresó al gobierno de los Estados Unidos de América la necesidad de que este último intervenga en los procedimientos judiciales en apoyo

9 LaGrand, Provisional measures, Order of 3 March 1999, cit., nota 7, párr. 19 (trad. del autor). Véase al respecto la declaración del juez Oda, quien hizo una crítica feroz a Alemania por haber presentado la demanda horas antes de la ejecución del segundo hermano LaGrand, al señalar que la corte no es un tribunal penal de apelaciones o de habeas corpus.

10 En esta etapa, el análisis de la jurisprudencia de la corte y los consejos del eminente jurista Santiago Oñate, en su carácter de embajador de México ante el Reino de los Países Bajos, y representante de nuestro país ante la CIJ, y luego agente de México en este caso junto con el autor, fueron absolutamente determinantes para definir la estrategia jurídica de México. 
de los nacionales mexicanos cuyos derechos, conforme al artículo 36, hubiesen sido violados, con vistas a obtener que los tribunales revisen y reconsideren los veredictos de culpabilidad y las penas, especialmente a la luz de las determinaciones de la CIJ en LaGrand. Asimismo, el gobierno federal de los Estados Unidos de América debería informar a las juntas de perdones que, cuando no fuere posible reponer la totalidad del procedimiento que condujo al veredicto de culpabilidad y a la pena de muerte, la conmutación de tal pena por la cadena perpetua constituye una reparación adecuada de la violación del artículo 36. En este sentido, el gobierno de los Estados Unidos de América no debería limitarse a exhortar a las juntas locales de perdones y a los gobernadores a "considerar" las violaciones del artículo 36.

No obstante, el Departamento de Estado reiteró que, con base en la libertad de medios que señaló la CIJ en el fallo LaGrand, su intervención consiste en pedir a las mencionadas autoridades administrativas que "revisen y reconsideren con cuidado" la violación del artículo 36. Sin embargo, no hay garantía de que la junta de perdones o el gobernador siga el consejo del Departamento de Estado. Era más que obvio que no podía esperarse más de la negociación. Sólo quedaba el recurso judicial.

El 9 de enero de 2003, en mi carácter de agente de México, y tras haber informado telefónicamente al consultor jurídico del Departamento de Estado de los Estados Unidos de América, presenté al secretario de la Corte Internacional de Justicia en La Haya, sede del tribunal, la demanda en contra de Estados Unidos de América, junto con una solicitud de medidas provisionales.

Este ensayo pretende sólo servir de guía a la lectura del fallo. No constituye en modo alguno un comentario o una exégesis de los muy diversos puntos de derecho que contiene el razonamiento de la corte. Busca simplemente colocar al lector en condiciones de comprender los motivos que llevaron a México a interponer este recurso, al tiempo que proporciona los antecedentes inmediatos de la decisión de la corte.

El único tema en el que intentaré hacer un análisis de la decisión es el relativo a la reparación ordenada en el fallo Avena, porque es en éste en el que puede mejor apreciarse el avance del derecho internacional y la contribución que haga esta decisión a la defensa de los derechos de las personas que son arrestadas o detenidas, por cualquier motivo, en un país que no es el suyo. 


\section{LOS ARGUMENTOS DE MÉXICO ${ }^{11}$}

\section{Los hechos que originan la demanda}

El gobierno de México tiene conocimiento de que las autoridades competentes de los Estados Unidos de América han detenido, juzgado y condenado a muerte a 54 nacionales mexicanos al cabo de procedimientos judiciales en los que tales autoridades violaron las obligaciones que les impone el artículo 36 de la Convención de Viena.

Estas violaciones, constantes y repetidas, han impedido que México ejerza los derechos de protección consular que le asisten, conforme a los artículos 5 y 36 de la Convención de Viena, generando así un grave perjuicio a los derechos de México, así como a los derechos de sus nacionales.

Hoy, 54 nacionales mexicanos, víctimas de estas violaciones, yacen en los corredores de la muerte en Estados Unidos de América. Todos han llevado su caso ante las instancias judiciales locales de los Estados Unidos de América. Muchos de ellos lo han hecho también al nivel de las jurisdicciones federales. En varios de estos casos, el gobierno de México ha intervenido a favor de sus nacionales ante dichas instancias y no ha escatimado esfuerzo diplomático alguno ante las autoridades de los Estados Unidos de América con el fin de que sus derechos y los de sus nacionales sean debidamente respetados.

En efecto, durante los últimos seis años, México ha presentado a los Estados Unidos de América un gran número de notas diplomáticas de protesta relativas a los casos de veinte nacionales mexicanos condenados a la pena de muerte, en las que se substanciaban las violaciones recurrentes del artículo 36 de la Convención de Viena y en las que se pedía al gobierno de los Estados Unidos de América que transmitiera a las autoridades locales la necesidad de tomar las medidas necesarias para salvaguardar los derechos fundamentales del condenado.

11 El conjunto de la argumentación mexicana se halla contenido en la demanda, en la memoria y en los alegatos orales del caso Avena, los cuales se desahogaron durante las audiencias públicas del 21 de enero de 2003 y del 15-19 de diciembre de 2003. Véase Avena and other Mexican Nationals (Mexico v. United States of America), ICJ Report 2004, http://www.icj-cij.org/. Para los efectos de este artículo, se presenta la síntesis de estos argumentos, tal como fue expuesta al secretario de la corte por el autor, en su carácter de agente de México, en una declaración leída en francés (trad. del autor). 
Del mismo modo, el gobierno de México, cuando consigue enterarse de que alguno de sus nacionales ha sido puesto bajo cualquier forma de detención, coadyuva a su defensa ante los tribunales competentes, con el fin de obtener reparación al daño sufrido el cual, con base en lo establecido por la CIJ en el fallo LaGrand, debería consistir en la revisión y la reconsideración del veredicto de culpabilidad y de la pena.

Sin embargo, de manera invariable, los tribunales de los Estados Unidos de América se han negado a considerar las violaciones del artículo 36, con base en la doctrina de derecho interno conocida como "doctrina de la preclusión procesal" (Procedural default doctrine), no obstante lo dicho por la corte al respecto en el fallo LaGrand. ${ }^{12}$

Finalmente, México solicitó y obtuvo una opinión consultiva de la Corte Interamericana de Derechos Humanos que precisa y aclara el contenido y el alcance de los derechos que tiene todo Estado parte de la Convención de Viena, así como de los derechos reconocidos a los individuos que se encuentre en un país que no es el suyo. Estos derechos individuales fueron calificados por la Corte Interamericana como auténticos derechos humanos. La Corte de San José concluyó que una ejecución llevada a cabo en violación del artículo 36 de la Convención de Viena constituiría una privación arbitraria de la vida en contravención del Pacto Internacional de Derechos Civiles y Políticos. ${ }^{13}$

No obstante estos esfuerzos, las autoridades competentes del gobierno de los Estados Unidos de América se han abstenido de adoptar las medidas necesarias para poner término a las violaciones que son objeto

12 LaGrand, Judgment, op. cit., nota 7, párr. 91. "The procedural default rule prevented them [the US courts] from attaching any legal significance to the fact, inter alia, that the violation of the rights set forth in Article 36, paragraph 1, prevented Germany, in a timely fashion, from retaining private counsel for them [the LaGrand brothers] and otherwise assisting in their defence as provided by the Convention. Under these circumstances, the procedural default rule had the effect of preventing 'full effect [from being] given to the purposes for which the rights accorded under this article are intended', and thus violated paragraph 2 of Article 36".

13 Opinión consultiva 16/99, op. cit., nota 6, párr. 137. "Por lo anteriormente expuesto, la corte concluye que la inobservancia del derecho a la información del detenido extranjero, reconocido en el artículo 36.1.b) de la Convención de Viena sobre Relaciones Consulares, afecta las garantías del debido proceso legal, y en estas circunstancias, la imposición de la pena de muerte constituye una violación del derecho a no ser privado de la vida "arbitrariamente", en los términos de las disposiciones relevantes de los tratados de derechos humanos (v. g. Convención Americana sobre Derechos Humanos, artículo 4; Pacto Internacional de Derechos Civiles y Políticos, artículo 6), con las consecuencias jurídicas inherentes a una violación de esta naturaleza, es decir, las atinentes a la responsabilidad internacional del Estado y al deber de reparación". 
de la demanda. Desde 1997, Estados Unidos de América ha procedido a la ejecución de cuatro nacionales mexicanos.

La falta de voluntad de los Estados Unidos de América de tomar las medidas necesarias para permitir que surtan pleno efecto los fines a los que están enderezados los derechos del artículo 36, ${ }^{14}$ han llevado a México a presentar esta demanda. México invoca la jurisdicción de la corte, con el propósito de asegurar que sus derechos y los de sus nacionales sean definitivamente respetados y el daño sufrido sea reparado.

Por último, huelga decir que México en modo alguno justifica los hechos delictivos de los que son presuntamente responsables los nacionales mexicanos condenados a la pena de muerte, siempre que se demuestre tal responsabilidad. México tampoco cuestiona el derecho de los Estados Unidos de América de imponer la pena de muerte por la comisión de ciertos delitos graves: esta instancia en modo alguno pretende demostrar que la imposición de la pena de muerte esté prohibida per se por el derecho internacional positivo.

\section{La competencia de la corte}

En virtud del artículo 36, párrafo primero, del Estatuto de la Corte, "La competencia de la corte se extiende... a todos los asuntos especialmente previstos en... los tratados y convenciones vigentes".

México y los Estados Unidos de América son, en tanto que miembros de las Naciones Unidas, parte del Estatuto de la Corte, y son, por otro lado, parte de la Convención de Viena, así como del Protocolo Facultativo sobre Jurisdicción Obligatoria para la Solución de Controversias que acompaña a la convención. El artículo 1 de dicho protocolo dispone que: "Las controversias originadas por la interpretación o aplicación de la convención se someterán obligatoriamente a la Corte Internacional de Justicia, que a este título podrá entender en ellas a demanda de cualquiera de las partes en la controversia que sea parte en el presente protocolo".

México concluye, en consecuencia, que las cuestiones objeto de esta controversia caen bajo la competencia de la corte.

14 El artículo 36 dispone en su párrafo segundo que: "Las prerrogativas a las que se refiere el párrafo 1 de este artículo se ejercerán con arreglo a las leyes y reglamentos del Estado receptor, debiendo entenderse, sin embargo, que dichas leyes y reglamentos no impedirán que tengan pleno efecto los derechos reconocidos por este artículo". 


\section{El derecho aplicable a la controversia}

El artículo 36 de la Convención de Viena "instituye un régimen en el cual los diferentes elementos están interrelacionados y que está concebido para facilitar la implementación del sistema de protección consular". ${ }^{15}$ Con este fin, la convención otorga derechos tanto al Estado que envía, como a los nacionales de ese primer Estado en la jurisdicción de otro Estado parte.

El inciso b) del párrafo primero del artículo 36 de la Convención de Viena determina las modalidades según las cuales debe llevarse a cabo la notificación consular, con el fin de hacer efectivo el ejercicio de esos derechos. Esta disposición prevé igualmente que las autoridades del Estado receptor debe informar "sin dilación" a todo nacional de otro Estado que "sea arrestado de cualquier forma, detenido o puesto en prisión preventiva" de su derecho a ponerse en contacto con su consulado. Del mismo modo, "si el interesado lo solicita, las autoridades competentes del Estado receptor deberán informar sin retraso alguno a la oficina consular competente en ese Estado cuando, en su circunscripción, un nacional del Estado que envía sea arrestado de cualquier forma, detenido o puesto en prisión preventiva."

Si las autoridades de un Estado no cumplen con estas obligaciones, un extranjero detenido no estará necesariamente en conocimiento de sus derechos y por ende no tendrá la posibilidad de ponerse en comunicación con su consulado. Igualmente, si estas obligaciones no son respetadas, será extremadamente difícil para un consulado tener conocimiento de la detención de su nacional. Si los agentes consulares no tienen conocimiento de que ha ocurrido una detención de alguno de sus nacionales, no estarán en condiciones de ejercer los derechos que les reconocen los incisos a) y b) del párrafo primero del artículo 36, a saber el derecho de visitarle, de comunicar con él, de organizar su defensa ante los tribunales que habrán de juzgarle y, en general, de prestarle la asistencia que pudiera requerir.

De esta forma, como la corte lo constató en el caso LaGrand, con el fin de determinar la violación de las disposiciones de la Convención de Viena "es irrelevante el saber si Alemania habría ofrecido o no asistencia consular; 'y si un veredicto diferente habría sido pronunciado. Es sufi- 
ciente el constatar que la convención le confería esos derechos' ${ }^{16}$ y que habrían podido ser usados, de haberlo deseado el nacional del Estado que envía y de no habérselo impedido el Estado receptor".

De acuerdo con la información de que dispone México, 54 nacionales mexicanos han sido detenidos, juzgados y condenados a la pena de muerte: en todos los casos, las autoridades de los Estados Unidos de América omitieron informar "sin dilación" a los interesados de su derecho a la protección consular. En ningún caso, los Estados Unidos de América han reconocido que los nacionales mexicanos tienen derecho a la "revisión y reconsideración del veredicto de culpabilidad y de la pena, tomando en cuenta la violación de los derechos previstos en la convención". ${ }^{17}$

El gobierno de los Estados Unidos de América es plenamente responsable de los actos de las subdivisiones políticas que lo constituyen. El hecho de no haber permitido el respeto de los derechos de los nacionales mexicanos, tal y como están previstos en el artículo 36 de la Convención de Viena, y el hecho de no garantizar la existencia de un mecanismo efectivo de revisión y reconsideración de los veredictos de culpabilidad y de las penas cuando tales derechos no han sido respetados, constituye una clara violación de parte de los Estados Unidos de América de sus obligaciones conforme a la Convención de Viena.

Además de los derechos individuales que consagra la Convención de Viena, y que fueron reconocidos como tales por la corte en el caso LaGrand, ${ }^{18}$ la convención reconoce también una serie de derechos al Estado que envía. Estados Unidos de América tiene la obligación de permitir que México pueda comunicar con su nacional y esté en condiciones de prestarle la asistencia que pudiere requerir. El hecho de que Estados Unidos de América no haya procedido a las notificaciones previstas en el inciso b) del párrafo primero del artículo 36, impidió a México ejercer los derechos que le confieren los artículos 5 y 36 de la Convención de Viena.

Asimismo, en virtud del mismo artículo 36, párrafo segundo, de la Convención de Viena, y del artículo 26 de la Convención de Viena sobre

16 Idem..

17 LaGrand, Judgment, op. cit., nota 7, párr. 125 (trad. del autor).

18 Ibidem, párr. 77. 
el Derecho de los Tratados, ${ }^{19}$ los Estados Unidos de América tienen la obligación de asegurar que sus leyes y reglamentos internos no sean obstáculo para que "tengan pleno efecto los derechos reconocidos por este artículo".

Finalmente, de conformidad con el artículo 27 de la Convención de Viena sobre el Derecho de los Tratados ${ }^{20}$ que es la expresión codificada del derecho consuetudinario, los Estados Unidos de América no pueden invocar doctrinas o reglas extraídas de su derecho interno, ni hacer valer que los actos violatorios de las obligaciones internacionales mencionadas han sido cometidos por órganos subordinados o por otro nivel de gobierno, o por otro poder, inclusive el Poder Judicial, para justificar el incumplimiento de sus obligaciones.

\section{Las solicitudes de México}

En la demanda, México formuló sus peticiones a la corte en los siguientes términos: ${ }^{21}$

El gobierno de los Estados Unidos Mexicanos, por lo tanto, solicita de la corte que declare y falle:

1. Que los Estados Unidos al detener, arrestar, juzgar, declarar culpables y condenar a los 54 nacionales mexicanos que se encuentran en la antesala de la muerte y que se señalan en esta demanda, violaron sus obligaciones jurídicas internacionales para con México, en lo relativo a los derechos propios que México posee y con relación al ejercicio de su derecho a brindar protección consular a sus nacionales, según lo disponen los artículos 5 y 36 de la Convención de Viena, respectivamente;

2. Que México tiene por lo tanto, derecho a la restitutio in integrum;

3. Que los Estados Unidos tienen la obligación jurídica internacional de abstenerse de aplicar la doctrina de la preclusión procesal (procedural default), o cualquier otra doctrina de su legislación interna de manera tal que

19 El artículo 26 de la Convención de Viena sobre el Derecho de los Tratados dispone que: "Todo tratado en vigor obliga a las partes y debe ser cumplido por ellas de buena fe", La Comisión de Derecho Internacional y su Obra, Naciones Unidas, Número de venta S. 95. V. 6, p. 357.

20 Por su parte, el artículo 27 de la Convención de Viena sobre el Derecho de los Tratados establece que: "Una parte no podrá invocar disposiciones de su derecho interno como justificación del incumplimiento de un tratado", Idem..

21 Avena, Application instituting proceedings, op. cit., nota 11, pp. 104-106, párr. 281 (trad. del autor). 
obstaculice el ejercicio de los derechos conferidos por el artículo 36 de la Convención de Viena;

4. Que los Estados Unidos deben, según el derecho internacional, respetar las obligaciones jurídicas internacionales antes mencionadas, en el caso de que, en el futuro, se produjese un arresto, o se llevara a cabo un proceso penal en contra de los 54 nacionales mexicanos que se encuentran en la antesala de la muerte, o en contra de cualquier otro nacional mexicano que se encontrare en su territorio, sea ese acto de parte de un poder constituido, legislativo, ejecutivo, judicial o cualquier otro, de jerarquía superior o subordinada en la organización de los Estados Unidos o que las funciones de dicho poder tengan carácter internacional o interno;

5. Que el derecho a la notificación consular garantizado por la Convención de Viena forma parte de los derechos humanos;

y que, de conformidad con las obligaciones jurídicas internacionales antes mencionadas:

1. Los Estados Unidos deben restaurar el status quo ante, es decir, reestablecer la situación existente previa a los actos de: detención, enjuiciamiento, declaración de culpabilidad y condenación de los nacionales mexicanos cometidos en contravención a las obligaciones jurídicas internacionales de los Estados Unidos;

2. Los Estados Unidos deben adoptar medidas necesarias y suficientes para garantizar que las normas de su derecho interno otorguen pleno efecto a los fines perseguidos por los derechos previstos en el artículo 36;

3. Los Estados Unidos deberán tomar medidas necesarias y suficientes para establecer conforme a derecho una reparación eficaz contra la violación a los derechos otorgados a México y a sus nacionales por el artículo 36 de la Convención de Viena, lo cual incluye evitar que se impongan, como una cuestión de derecho interno, penalidades procesales por no presentar oportunamente una demanda o una excepción en el marco de la defensa con base en la Convención de Viena, en aquellas circunstancias en que las autoridades competentes de los Estados Unidos hayan violado su obligación de informar al nacional mexicano de sus derechos que le confiere la Convención de Viena; y

4. Los Estados Unidos, en vista de la práctica recurrente y sistemática de las violaciones señaladas en esta demanda, deben brindar a México plena garantía de que tales actos ilícitos no volverán a producirse". 


\section{Juez ad hoc}

De conformidad con lo dispuesto en el artículo 31, párrafo 2 del estatuto y en el artículo 35, párrafo 1, del Reglamento de la Corte, el gobierno de México declara su intención de designar un juez ad hoc. ${ }^{22}$

\section{Medidas provisionales}

Junto con la demanda, México solicitó a la corte, de conformidad con el artículo 41, párrafo 1, de su estatuto que, mientras resuelve sobre el fondo de la controversia, emita una ordenanza indicando las medidas provisionales que los Estados Unidos de América deban tomar, con el fin de que ninguno de los 54 nacionales mexicanos objeto del litigio sea ejecutado y que no se fije fecha de ejecución en relación con alguno de ellos.

En el curso de los siguientes seis meses, tres nacionales mexicanos - César Fierro, Roberto Moreno Ramos y Osbaldo Torres- deberían ser ejecutados, a menos que la corte decidiera indicar las medidas provisionales que exige esta circunstancia de urgencia. La ejecución de César Fierro podría fijarse para febrero de 2003, la de Roberto Moreno Ramos para marzo de 2003 y la de Osbaldo Torres para julio de 2003.

El objeto de las medidas provisionales es el de "resguardar los derechos de cada una de las partes": 23 la restitutio in integrum que solicita México, a título de reparación por las violaciones de parte de Estados Unidos de América a las obligaciones que se derivan del artículo 36 de la Convención de Viena, no podría materializarse si cualquiera de los individuos objeto de la controversia es ejecutado.

No cabe duda tampoco de la urgencia que revisten las medidas provisionales. El derecho internacional reconoce el carácter esencial del derecho a la vida. El artículo 6 del Pacto Internacional de Derechos Civiles y Políticos, del que Estados Unidos de América es parte, dispone que

22 Cuando la corte incluye entre los jueces a uno de la nacionalidad de una de las partes, la otra puede designar a una persona de su elección para que tome asiento en calidad de juez ad hoc. Toda vez que la corte cuenta con un juez de nacionalidad estadounidense (el juez Thomas Buergenthal), México designó, mediante carta dirigida al secretario de la corte, con fecha 13 de enero de 2003, a Bernardo Sepúlveda, ex canciller de México y miembro de la Comisión de Derecho Internacional de las Naciones Unidas.

23 Artículo 41, Estatuto de la CIJ. 
todo ser humano tiene el derecho inherente a la vida y que las leyes de cada Estado deben proteger este derecho.

Si la corte se abstiene de indicar las medidas provisionales solicitadas, los Estados Unidos de América ejecutarán a César Fierro, a Roberto Moreno Ramos y a Osbaldo Torres o a cualquier otro nacional mexicano que se halla en el corredor de la muerte, antes de que la corte haya podido apreciar los argumentos de fondo que presenten las partes.

Si ello llegara a suceder, México sería para siempre privado de la posibilidad de reivindicar sus derechos y de ejercer la protección diplomática para hacer valer los derechos individuales de sus nacionales.

En suma, las medidas provisionales son necesarias para resguardar los derechos de México, que incluyen la preservación de la vida de sus nacionales, mientras la corte conoce del fondo del asunto. Tales medidas son también indispensables para asegurar que la corte conserve la posibilidad de ordenar las medidas que correspondan para restaurar los derechos violados por Estados Unidos de América.

\section{LOS ARGUMENTOS DE LOS ESTADOS UNIDOS DE AMÉRICA ${ }^{24}$}

Estados Unidos de América acudió a la Corte Internacional de Justicia con una estrategia jurídica radicalmente distinta de la que utilizó en el caso LaGrand.

En el primer litigio, Estados Unidos de América optó por reconocer la existencia de la violación de los derechos de los hermanos LaGrand y de Alemania, pero se esforzó por limitar la interpretación en torno al alcance de la asistencia consular que hubieran recibido y su impacto en el procedimiento que se les siguió. Consecuentemente, Estados Unidos de América alegó que la violación de la Convención de Viena se subsanaba, como había hecho, con la mera presentación de disculpas al Estado alemán.

En este contexto, los abogados de los Estados Unidos de América centraron su argumentación en el presunto abuso de la competencia de la

24 Al igual que en el caso de México, los argumentos de los Estados Unidos de América están contenidos en la Contramemoria con la que Estados Unidos de América contesta a la demanda inicial y a la Memoria de México, y en los alegatos orales, los cuales tuvieron lugar el 21 de enero de 2003 y del 15-19 de diciembre de 2003. 
Corte Internacional de Justicia por parte de Alemania, a la luz de las pretensiones alemanas.

Las medidas provisionales, decretadas motu proprio por la corte, y la controversia sobre su obligatoriedad fueron en esencia los temas más relevantes de este litigio. Sin embargo, ni los hechos ni las violaciones fueron rebatidas por Estados Unidos de América.

En Avena, Estados Unidos de América sabía que no podía volver sobre lo que ya había decidido la corte en LaGrand.

Así las cosas, optó por presentar su defensa resaltando las virtudes del fallo LaGrand, con el argumento central de que la corte ya había fallado al respecto y que la reparación decidida en esa ocasión consagra la libertad de medios para llevar a cabo la revisión y la reconsideración de los veredictos de culpabilidad y de las penas. Los mecanismos de clemencia eran, en efecto, el medio elegido por Estados Unidos de América para cumplir con la reparación y así lo harían no sólo en relación con nacionales de Alemania, sino con cualquier otro.

Al mismo tiempo, Estados Unidos de América repitió la argumentación en torno a que México estaba presuntamente abusando de la corte, y a que el caso, en realidad, tenía más que ver con la pena de muerte en los Estados Unidos de América que con la aplicación y la interpretación de la Convención de Viena.

Ante el hecho de que ninguno de los nacionales mexicanos tenía aun fecha de ejecución al momento en que México interpuso la demanda y solicitó las medidas provisionales, Estados Unidos de América cuestionó que se configuraran las condiciones para la orden de medidas provisionales.

Sin embargo, llegado al fondo, y a diferencia de lo sucedido en LaGrand, Estados Unidos de América negó la casi totalidad de las pruebas aportadas por México, tanto en lo tocante a los hechos como en lo relacionado con las violaciones. Llegó incluso al extremo de afirmar, sin jamás aportar evidencia alguna, que la mayoría de los condenados tenía la nacionalidad estadounidense y no rebatió las pruebas ofrecidas por México.

Entre otros argumentos, Estados Unidos de América desestimó las violaciones queriendo demostrar que México tampoco cumple con lo prescrito en la Convención de Viena, como una de las excepciones en materia de admisibilidad de las peticiones de México. Esta excepción, al igual que las demás, fue desechada por la corte. 
Se trató en síntesis de una estrategia tendiente a descalificar el fundamento de las pretensiones mexicanas que no estuvo exenta de intentos por intimidar a la corte, como señaló en su alegato México.

\section{LAS DECISIONES DE LA CORTE}

\section{Ordenanza sobre medidas provisionales}

El 5 de febrero de 2003, la corte rindió su ordenanza respecto de la solicitud de medidas provisionales presentada por México, tras haber oído los argumentos de las partes en la audiencia del 21 de enero de 2003.

En su ordenanza, la corte indicó las siguientes medidas.

i) Los Estados Unidos de América deberán tomar todas las medidas necesarias para asegurar que los señores César Roberto Fierro Reyna, Roberto Moreno Ramos y Osbaldo Torres Aguilera no sean ejecutados mientras no haya sido rendido el fallo definitivo en la presente instancia;

ii) El gobierno de los Estados Unidos de América deberá informar a la corte acerca de todas las medidas que adopte en aplicación de la presente ordenanza. ${ }^{25}$

Nos hemos referido ya a los argumentos de las partes respecto de la cuestión de saber si las medidas solicitadas por México se justificaban o no. No volveremos sobre ellos; baste señalar que la ordenanza y su cumplimiento por parte de los Estados Unidos de América tenían una importancia crucial para México.

Por una parte, por el mero hecho de que con estas medidas, al preservar la vida de aquellos condenados cuya ejecución podía ser inminente, se resguardaban los derechos de México mientras la corte resolvía sobre el fondo.

Por la otra, porque esta ordenanza intervenía luego de que la corte, en el caso LaGrand, había declarado que las medidas provisionales que ordenara conforme al artículo 41 de su estatuto, revisten carácter obligatorio. La corte había tenido que hacer esta determinación en vista de que Estados Unidos de América, tras la ejecución del segundo hermano 
LaGrand, había alegado que las medidas provisionales no son obligatorias. ${ }^{26}$ Esta determinación de la corte resolvió un largo e intenso debate doctrinal, motivado en parte por la redacción que se contiene en el artículo 41 del Estatuto de la CIJ en el que el uso del verbo "indicar" ["La corte tendrá facultad para indicar...] en lugar de "ordenar", por ejemplo, dio lugar a que se suscitaran dudas respecto de la naturaleza de las medidas provisionales de la corte.

Sin embargo, como ya se ha dicho, la corte en forma implícita dio cierta razón a la argumentación de los Estados Unidos de América sobre lo tardío de la solicitud de medidas provisionales que dejó en realidad poco tiempo a las autoridades de los Estados Unidos de América para tomar las medidas necesarias con el fin de evitar la ejecución de Walter LaGrand, aunque aclaró que "the various competent United Status authorities failed to take all the steps they could have taken to give effect to the Court's Order". ${ }^{27}$

De ahí la importancia del momento en que México solicitara las medidas provisionales, si en verdad se quería dar a Estados Unidos de América la posibilidad de tomar las medidas que la ordenanza exigiera.

Debe notarse, en este contexto, que la corte, quizás con el ánimo de no dejar dudas al destinatario de la ordenanza, modificó de manera significativa la redacción del dispositivo de su ordenanza en Avena, frente al lenguaje utilizado en LaGrand.

Mientras que en el caso LaGrand, la corte dice que Estados Unidos de América "should take all measures at its disposal", ${ }^{28}$ en el caso Avena el máximo tribunal ordenó que los Estados Unidos de América "shall take all measures necessary to". ${ }^{29}$

26 LaGrand, Judgment, op. cit., nota 7, párrs. 92-116. En el párrafo 109, la corte, con una contundencia que no deja lugar a dudas, estableció que: "In short, it is clear that none of the sources of interpretation referred to in the relevant Articles of the Vienna Convention on the Law of Treaties, including the preparatory work, contradict the conclusions drawn from the terms of Article 41 read in their context and in the light of the object and purpose of the Statute. Thus, the Court has reached the conclusion that orders on provisional measures under Article 41 have binding effect".

27 Ibidem, párr. 104.

28 LaGrand, Provisional measures, Order of 3 March 1999, op. cit., nota 9, párr. 29.

29 Avena, Provisional measures, Order of 5 February 2003, op. cit., nota 11, párr. 59. Veáse también Aceves, William J., "Avena and Other Mexican Nationals (Mexico v. United States), International Court of Justice Order of Provisional Measures in case of alleging breaches of Vienna Convention on Consular Relations", American Journal of International Law, vol. 97, núm. 4, 2003, pp. 927 y 928 . 
Asimismo, si bien la corte ordenó tales medidas sólo en relación con los casos de César Fierro, Roberto Moreno Ramos y Osbaldo Torres, se reservó expresamente el derecho de hacerlo en relación con las demás personas listadas en la demanda de México, si las circunstancias llegasen a requerirlo..$^{30}$

En su decisión, la corte tomó en cuenta el riesgo de que los tres nacionales mexicanos mencionados fueran ejecutados en cuestión de meses o incluso de semanas, admitiendo así el perjuicio irreparable que ello ocasionaría a los derechos que la corte podría reconocer a México, al considerar que las reglas y los plazos que rigen el otorgamiento de la clemencia y las ejecuciones de las penas capitales en algunos estados de Estados Unidos de América, hacían necesario ordenar las medidas solicitadas, aun cuando todavía no se hubiese fijado fecha alguna en relación con ninguna de las personas listadas en la demanda de México. ${ }^{31}$

Como lo reconociera México en voz de su agente, Estados Unidos de América cumplió con lo requerido en la ordenanza ${ }^{32}$ durante el tiempo que medió entre la presentación de la demanda y la conclusión del caso, si bien tres semanas antes de la audiencia en la que se daría lectura del fallo sobre el fondo (31 de marzo de 2004), no impidió que las autoridades de Oklahoma fijaran fecha de ejecución a Osbaldo Torres para el 18 de mayo de 2004.

El cumplimiento de parte de Estados Unidos de América de la ordenanza del 5 de febrero de 2003 es por sí solo prueba de la irrelevancia de todos los argumentos invocados en torno a la presunta imposibilidad jurídica de tomar las medidas que fueren necesarias para evitar la ejecución de los condenados, dada la estructura federal de los Estados Unidos de América que determina que los asuntos penales son competencia exclusiva de las entidades federativas.

Así, Estados Unidos de América había argumentado que la aquiescencia de la corte a la solicitud de México "would constitute a wholly unprecedented and unwarranted interference with the sovereign rights of the United States". ${ }^{33}$

$30 \quad$ Ibidem, párr. 56.

31 Ibidem, párrs. 54 y 55.

32 Avena, Merits, Public sitting, 15 de diciembre de 2003, CR 2003/24, op. cit., nota 11, párrs. 44-46.

33 Avena, Provisional measures, Public sitting, 21 de enero de 2003, op. cit., nota 11, CR 2003/2, párr. 2.9, alegato de Estados Unidos de América en voz del abogado Stephen Mathias. 
Sin embargo, como señaló México en su alegato, Estados Unidos de América dispone de una gran variedad de medios, en el ámbito interno, para dar cumplimiento a la ordenanza de la corte, ${ }^{34}$ aunque stricto sensu éste no debería ser un tema en el marco de un litigio internacional. Un Estado no puede invocar disposiciones de su derecho interno para justificar el incumplimiento de obligaciones conforme al derecho internacional, tal como establece la Convención de Viena sobre el Derecho de los Tratados en su artículo $27 \mathrm{y}$ como lo ha señalado la corte en repetidas ocasiones. ${ }^{35}$

\section{Fallo sobre el fondo}

El fallo de la corte significa para México, y para la comunidad internacional en su conjunto, contar, a partir de ahora, con una interpretación definitiva del alcance de las obligaciones derivadas del artículo 36 de la Convención de Viena. En el caso particular de México, al tiempo que fortalece los argumentos jurídicos que México hará valer para promover los derechos de los mexicanos que sean arrestados por cualquier motivo, la decisión de la CIJ aporta una serie de determinaciones de enorme trascendencia para los casos individuales que originaron la intervención del gobierno mexicano a través de la protección diplomática. Veamos, en primer término, las respuestas de la corte a las solicitudes de México, en relación con el fondo de la controversia.

153. Por estas razones,

La corte,

...

(4) Por catorce votos a uno,

Dice que, al no informar sin dilación, a raíz de su detención, a los 51 nacionales mexicanos referidos en el numeral 106(1) que antecede, de sus derechos conforme al artículo 36, párrafo 1 inciso b) de la Convención de

34 Ibidem, CR 2003/ 1, párrs. 129-139; alegato de México en voz del abogado Donald F. Donovan. Véase también Carter, Linda E., "Compliance with ICJ Provisional Measures and the meaning of review and reconsideration under the Vienna Convention on Consular Relations: Avena and Other Mexican Nationals (Mexico v. U. S.)", Michigan Journal of International Law, vol. 25, núm. 1, 2003, pp. 126-128.

35 ICJ, "Reparation for injuries suffered in the service of the United Nations, Advisory Opinion of 11April 1949", ICJ Reports 1949, párr. 174; y también ICJ, "Difference relating to immunity from legal process of a special rapporteur of the Commission on Human Rights, Advisory Opinion of 29 April 19990148, ICJ Reports 1999, párr. 62. 
Viena sobre Relaciones Consulares del 24 de abril de 1963, los Estados Unidos de América violaron las obligaciones que les corresponden conforme a ese inciso;

(5) Por catorce votos a uno,

Dice que, al no notificar sin retraso a la oficina consular correspondiente, la detención de los 49 nacionales mexicanos referidos en el numeral 106(2) de este fallo, y por tal motivo privar a los Estados Unidos Mexicanos del derecho para que oportunamente prestaran la asistencia que se prevé en la Convención de Viena a favor de los individuos afectados, los Estados Unidos de América violaron las obligaciones que les corresponden bajo el artículo 36, párrafo 1 inciso $b$ );

(6) Por catorce votos a uno,

Dice que, con relación a los 49 nacionales mexicanos referidos en el numeral 106(3) que antecede, los Estados Unidos de América privaron a los Estados Unidos Mexicanos del derecho a que, de manera oportuna, se comunicaran y tuvieran acceso a dichos nacionales para visitarlos en su detención y, por lo tanto, violaron las obligaciones que les corresponden según el artículo 36, párrafo 1 incisos a) y c), de la convención;

(7) Por catorce votos a uno,

Dice que, con relación a los 34 nacionales mexicanos a que se refiere el numeral 106(4) que antecede, los Estados Unidos de América privaron a los Estados Unidos Mexicanos del derecho a organizar oportunamente la defensa de dichos nacionales ante los tribunales, y por lo tanto, violaron las obligaciones que recaen sobre ellos de conformidad con el artículo 36, párrafo 1 inciso $c$ ), de la convención;

(8) Por catorce votos a uno,

Dice que, al no permitir la revisión y la reconsideración a la luz de los derechos establecidos en la convención, de los veredictos de culpabilidad y de las penas de los señores César Roberto Fierro Reyna, Roberto Moreno Ramos y Osvaldo Torres Aguilera, después de haberse probado las violaciones que se señalan en inciso 4) que antecede con respecto a dichos individuos, los Estados Unidos de América violaron la obligación que les corresponden de conformidad con el artículo 36, párrafo 2, de la convención;

(9) Por catorce votos a uno,

Dice que para proporcionar la reparación adecuada en este caso, los Estados Unidos de América están obligados a asegurar, por los medios de su elección, la revisión y la reconsideración de los veredictos de culpabilidad pronunciados y de las penas dictadas contra los nacionales mexicanos referidos en los párrafos (4), (5), (6) y (7) que anteceden; en las que se tome en cuenta tanto la violación a los derechos establecidos en el artículo 36 de la convención, como los numerales 138 al 141 de este fallo; 
(10) Por unanimidad,

Toma nota del compromiso de los Estados Unidos de América de asegurar la implementación de medidas específicas adoptadas en cumplimiento de sus obligaciones conforme al artículo 36, párrafo 1 inciso b) de la Convención de Viena; y dice que este compromiso debe ser considerado como satisfactorio a la petición de los Estados Unidos Mexicanos requiriendo seguridades y garantías de no repetición;

(11) Por unanimidad,

Dice que, no obstante, en caso de que nacionales mexicanos sean condenados a penas graves, sin haberse respetado los derechos que les concede el artículo 36, párrafo 1 inciso b), de la convención, los Estados Unidos de América están obligados a asegurar, por los medios de su elección, la revisión y la reconsideración del veredicto de culpabilidad y de la pena, de manera tal que se dé todo el peso requerido a la violación de los derechos establecidos en la convención, tomando en cuenta los numerales 138 al 141 de este fallo. ${ }^{36}$

En vista de la abundancia y riqueza del fallo, cuyas determinaciones la corte no limitó al párrafo dispositivo arriba transcrito, pero que encontramos también a lo largo y ancho del razonamiento de la corte, lo mejor será abordar este análisis, tema por tema, siguiendo el orden que utiliza el máximo tribunal en su decisión.

\section{A. Cuestiones de competencia y de admisibilidad}

Estados Unidos de América invocó cuatro causales de incompetencia de la corte para conocer de este asunto, así como cinco motivos por los que la corte debía, en su opinión, declarar inadmisibles las demandas de México.

En relación con las causales de incompetencia y de inadmisibilidad, México hizo valer los términos a los que están sujetas, de conformidad con el artículo 79 del Reglamento de la Corte que dispone que: "Cualquier excepción a la competencia de la corte o a la admisibilidad de la demanda o cualquier otra excepción sobre la cual requiere el demandado que la corte se pronuncie antes de continuar el procedimiento sobre el fondo, deberá formularse por escrito, tan pronto como sea posible, y a más tardar dentro de los tres meses siguientes a la fecha de entrega de la Memoria". 
En virtud de que la Memoria de México fue presentada el 23 de junio de 2003 y las excepciones invocadas por Estados Unidos de América están contenidas en su Contra-Memoria, entregada a la corte el 3 de noviembre de 2003, es decir más de un mes después del plazo previsto en el reglamento, México pidió a la corte que las declarase inadmisibles.

Si bien la corte subrayó "que las partes en los casos que se ventilan ante ella no podrían, pretendiendo 'reservarse su derecho' de tomar una $\mathrm{u}$ otra acción procesal, sustraer esas acciones de la aplicación de las disposiciones del estatuto y del Reglamento de la Corte", ${ }^{37}$ señaló que la regla invocada por México se aplica únicamente a las excepciones preliminares, es decir a aquellas que tienen como fin suspender el procedimiento en cuanto al fondo. Estados Unidos de América las hizo valer, en cambio, al mismo tiempo que presentó sus argumentos sobre el fondo, pues, por su naturaleza, tales excepciones deben ser examinadas al mismo tiempo que los argumentos de fondo. De ahí que la corte decidiera examinar la totalidad de las excepciones de Estados Unidos de América. ${ }^{38}$

Al respecto, debe aclararse que México reconoció en su alegato que las excepciones de Estados Unidos de América estaban a tal grado interrelacionadas con los argumentos de fondo que tendría que rebatirlas. No obstante, convenía pedir a la corte que las rechazara en virtud del sentido literal del artículo 79 de su reglamento, el cual había sido enmendado recientemente con vistas a acortar los plazos para el desahogo de los casos. Ello obligó a la corte, como hemos visto, a interpretar esta disposición de su reglamento y abocarse a examinar las excepciones planteadas por Estados Unidos de América.

En general, las excepciones en materia de competencia se fundamentaban en el hecho de que México pedía a la corte que se pronunciase sobre asuntos ajenos a la aplicación o a la interpretación de la Convención de Viena, pues en su demanda México solicitaría a la CIJ que intervenga en el funcionamiento del sistema de administración de justicia penal de los Estados Unidos de América.

La corte rechazó, una por una, las cuatro excepciones, al indicar que las demandas de México versan sobre la interpretación de la Convención 
de Viena, respecto de la cual la CIJ es competente con base en el Protocolo Facultativo. ${ }^{39}$

Por su parte, las excepciones relativas a la inadmisibilidad de las demandas de México, tienen que ver, en lo general, con el argumento de que México intentaba que la corte actuase a la manera de una jurisdicción de apelación en materia penal. Estados Unidos de América hizo valer también que México no puede pretender ejercer la protección diplomática a favor de sus nacionales, y justificar así su recurso a la corte, en tanto que estos nacionales no han agotado los recursos de la jurisdicción interna, incluyendo el mecanismo de la clemencia ejecutiva. ${ }^{40}$ En este contexto, Estados Unidos de América planteó que los individuos listados en la demanda mexicana tienen también la nacionalidad estadounidense, por lo que México no puede ejercer la protección diplomática a favor de personas que no tendrían derecho a los beneficios del artículo 36 de la Convención de Viena. México rebatió este argumento, indicando que:

Los tribunales de los Estados Unidos de América nunca han dado entrada a recurso judicial alguno promovido por un nacional extranjero por violaciones al artículo 36. Dichos tribunales declaran ya sea que el artículo 36 no crea un derecho individual, o bien que un nacional extranjero que ha sido privado de los derechos conforme al artículo 36, pero a quien en cambio se le han reconocido sus derechos previstos por la Constitución y las leyes estadounidenses, no puede demostrar la existencia de un perjuicio y por lo tanto no puede obtener reparación [y] concluye que los recursos judiciales disponibles son, por lo tanto, ineficaces. Con respecto al recurso de clemencia, México alega que no puede tomarse en cuenta para los efectos del principio del agotamiento de los recursos internos, en virtud de no tratarse de un recurso judicial. ${ }^{41}$

39 Ibidem, párr. 26-35 (trad. del autor).

40 Conviene aclarar al lector que la protección diplomática nada tiene que ver con la protección debida por el Estado receptor a las misiones y a los agentes diplomáticos ubicados en su territorio, conforme a la Convención de Viena sobre Relaciones Diplomáticas. Tampoco tiene que ver estrictamente con la protección consular que el Estado que envía dispensa a sus nacionales en el territorio del Estado receptor. Trátase de una institución que permite a un Estado, mediante una ficción jurídica, hacer suya la reclamación de una persona física o moral de su nacionalidad en contra de otro Estado, elevándola al rango de una controversia de derecho internacional para poder ser dirimida en tribunales internacionales. El ejercicio de esta prerrogativa del Estado está sujeto, sin embargo, a la regla del previo agotamiento de los recursos internos disponibles.

41 Avena, Judgment, op. cit., nota 11, párr. 39 (trad. del autor). Véase también el alegato de México en voz de Socorro Flores, CR 2003/25, párrs. 302-321, en particular los párrafos 305 y 306, en los que, citando jurisprudencia de la corte, México alegó que la regla del previo agotamiento de 
La corte, en primer término, reafirma la regla de oro que rige la institución de la protección diplomática, a saber que:

Los derechos individuales de los nacionales mexicanos conforme al párrafo 1 inciso (b) del artículo 36 de la Convención de Viena son derechos que deben ser exigidos, en todo caso y en primer lugar, en el sistema judicial interno de los Estados Unidos de América. Solamente cuando este proceso ha concluido y los recursos internos han sido agotados, podría entonces México hacer suyas las demandas individuales de sus nacionales a través del procedimiento de la protección diplomática. ${ }^{42}$

\section{Sin embargo:}

México no actúa solamente sobre esas bases. También presenta demandas que le son propias fundándose en el agravio que alega haber sufrido directamente y a través de sus nacionales, como resultado de la violación por los Estados Unidos de América, a las obligaciones que le correspondían conforme al artículo 36, párrafo 1 (a), (b) y (c). La corte desea recordar que en el caso LaGrand, reconoció que "el artículo 36, párrafo 1 [de la Convención de Viena], crea derechos individuales [para los nacionales involucrados], que pueden ser invocados ante esta corte por el Estado del cual la persona detenida tiene la nacionalidad" (ICJ, Reports 2001, p. 494, párr. 77). Desea, además, señalar que las violaciones a los derechos del individuo derivados del artículo 36, pueden implicar una violación a los derechos del Estado que envía, y que toda violación a los derechos de este último puede implicar violaciones a los derechos del individuo. En estas circunstancias especiales de interdependencia entre los derechos del Estado y los derechos individuales, México puede, al presentar una demanda en su propio nombre, solicitar que la corte resuelva una violación de los derechos que reclama haber sufrido, tanto directamente, como a través de la violación a los derechos individuales conferidos a sus nacionales por el artículo 36, párrafo 1(b). El principio del agotamiento de los recursos internos no se aplica a una demanda de esta naturaleza. Además, y por las razones que se acaban de explicar, la corte no encuentra necesario considerar las reclamaciones de México por violaciones bajo el rubro específico

los recursos internos "as indicated in the Barcelona Traction case... does not require from those concerned a clearly futile and pointless activity, or a repetition of what has been done in vain", así como en el caso de la Elettronica Sicula, en el cual la corte estableció que "for an international claim to be admissible, it is sufficient if the essence of the claim has been brought before the competent tribunals and pursued as far as permitted by local law and procedures, and without success".

42 Ibidem, párr. 40. 
de la protección diplomática. Sin que haya lugar, en esta fase, a tratar las cuestiones planteadas por el principio de preclusión procesal que México expuso en el numeral 39 que antecede, la corte en consecuencia, concluye que la segunda excepción de inadmisibilidad opuesta por los Estados Unidos de América no puede ser procedente. ${ }^{43}$

No es este el espacio para hacer un comentario exhaustivo sobre un dictum de la corte que dará mucho de que hablar, especialmente cuando la Comisión de Derecho Internacional se halla considerando la cuestión de la codificación del derecho que rige la protección diplomática.

Lo importante para nuestros efectos es que la CIJ confirma que la regla del previo agotamiento de los recursos internos admite excepciones, siendo una demanda como la de México una de esas excepciones y, con base en lo establecido en el fallo LaGrand, que los derechos individuales reconocidos en el artículo 36 pueden dar derecho al Estado de nacionalidad de acudir ante la corte, tanto con motivo de la afectación directa, como a través de la violación a los derechos individuales conferidos a sus nacionales por el artículo 36, párrafo 1(b).

La corte se abstuvo de decidir la procedencia del fundamento de la admisibilidad basada en el ejercicio de la protección diplomática, quizás como una manera de no tener que hacer una valoración sobre la efectividad de los recursos jurisdiccionales de los Estados Unidos de América, pero no llegó al punto de negar que México pudiera invocar su ejercicio.

La corte estimó, por otra parte, que la cuestión de la doble nacionalidad de los individuos contenidos en la demanda correspondía al fondo del litigio, por lo que se abstuvo de examinarla en esta etapa del procedimiento. De esta manera, la corte desechó las cinco excepciones en materia de admisibilidad y pasó a estudiar el fondo de los argumentos de las partes.

\section{B. Las violaciones del artículo 36 de la Convención de Viena}

Ante el alto número de casos individuales contenidos en la demanda, la diversidad de las situaciones procesales de cada uno de ellos y la natural, por demás comprensible, reticencia de la corte a entrar al ámbito del derecho penal de los Estados Unidos de América, podía esperarse que el máximo tribunal examinara el conjunto de las violaciones sin hacer con- 
sideraciones de tipo individual. En cambio, la corte se aboca a examinar la demanda caso por caso, excluye un caso por tratarse de un nacional estadounidense (Ramón Salcido) y divide los 51 casos restantes en categorías en función del tipo de violación a los derechos reconocidos en el párrafo 1 , incisos $(a),(b)$ y (c) del artículo 36 , así como a las obligaciones resultantes del párrafo 2 del mismo artículo 36.

Sobre la base de este análisis individual y de las pruebas aportadas por las partes, la corte llega a determinaciones diferenciadas que se contienen en las listas relacionadas en los numerales 106 y 114 del fallo, en las que concluye que Estados Unidos de América violó sus obligaciones conforme al artículo 36, párrafo 1 (b) en cada uno de los 51 casos presentados por México, al tiempo que privó a México de su derecho de proporcionar la asistencia consular, "sin importar el saber si México habría ofrecido o no asistencia consular"; "y si un veredicto diferente habría sido pronunciado. Es suficiente el constatar que la convención le confería esos derechos" (ICJ, Reports 2001, p. 492, párr. 74), "los que habrían podido ser usados". ${ }^{44}$

Por cuanto hace al derecho de los funcionarios consulares de organizar la defensa de sus nacionales en los tribunales, consignado en el inciso (c) del artículo 36, párrafo 1, la corte estima que no puede proporcionar una respuesta tan general pues, no obstante las obligaciones a cargo del Estado receptor, de cuyo cumplimiento depende el ejercicio de los derechos del Estado que envía:

Puede ser sin embargo, que la información que se haga del conocimiento del Estado que envía por otros medios, pueda aún permitir a sus funcionarios consulares brindar asistencia en la organización de la defensa de sus nacionales. En los siguientes casos, las autoridades consulares mexicanas supieron de la detención de sus nacionales a tiempo para proporcionar dicha asistencia, ya fuera a través de notificación de las autoridades de los Estados Unidos de América (aunque tardíamente en términos del artículo 36, párrafo 1 (b)) o mediante otros medios). ${ }^{45}$

Así, la corte excluyó 17 casos de la conclusión de que Estados Unidos de América violó sus obligaciones conforme al inciso (c) del artículo 36, párrafo 1. Esta distinción no afectará, como se verá más adelante, la 
obligación de reparar el daño causado mediante la revisión y la reconsideración del veredicto de culpabilidad y de la pena.

Al hacer esta tarea de disquisición entre los distintos casos, la corte tiene que detenerse en la cuestión de la nacionalidad de los individuos objeto del litigio. Reafirmando:

El principio bien establecido en derecho internacional, según el cual el litigante que busca establecer la existencia de un hecho tiene la carga de la prueba..., ${ }^{46}$ la corte estima que México debe demostrar que las 52 personas enumeradas en el numeral 16 que antecede tenían nacionalidad mexicana en el momento en que fueron detenidas; al respecto, señala que México ha presentado las actas de nacimiento y las declaraciones de nacionalidad, cuyos contenidos no han sido impugnados por los Estados Unidos... La corte concluye entonces que los Estados Unidos no se liberaron de la carga de la prueba que les correspondía respecto a que, ciertas personas de nacionalidad mexicana eran también nacionales de los Estados Unidos. ${ }^{47}$

\section{a. Las garantías del artículo 36 y los llamados "Derechos Miranda"}

En este contexto, la corte señala que sería preferible informarse sistemáticamente sobre la nacionalidad del interesado desde el momento de su detención, de manera que las obligaciones de la Convención de Viena puedan ser cumplidas. La corte prosigue que si el interesado fuese siempre informado de que, en caso de tener nacionalidad extranjera, tendría el derecho de pedir que su oficina consular sea notificada, el respeto a lo establecido por el artículo 36, párrafo 1 (b), se incrementaría significativamente. La corte sugiere entonces que tal información podría ser otorgada paralelamente a la lectura de los llamados "Derechos Miranda" ${ }^{48}$ Este dictum de la corte reviste especial importancia a la luz de la controversia, tanto en Avena como en LaGrand, sobre la cuestión de saber si los derechos del artículo 36 constituyen derechos humanos. México, consciente de que la corte no había querido abordar esta cuestión en el

46 Ibidem, párr. 55 (trad. del autor).

47 Ibidem, párr. 57 (trad. del autor).

48 Se trata, principalmente, del derecho a guardar silencio, del derecho a la presencia de un abogado durante el interrogatorio, y del derecho de asistencia de un abogado con cargo al gobierno, si la persona no tiene los medios para sufragarlo. 
caso LaGrand no obstante que Alemania se lo había pedido, recurrió a la opinión consultiva 16 de la Corte Interamericana de Derechos Humanos y a los trabajos preparatorios de la Convención de Viena sólo para argumentar que el derecho del artículo 36 "es tan fundamental, que su violación tiene ipso facto el efecto de viciar la totalidad del proceso penal ventilado en violación a dicho derecho". ${ }^{49}$ Sin embargo, la corte, deseando quizás dar alguna orientación a las partes sobre esta cuestión, manifestó que: "sin necesidad de pronunciarse acerca de saber si el derecho en cuestión es o no un derecho humano, la corte sin embargo, desea senalar que ni el texto, ni el objeto y la finalidad de la convención, ni indicación alguna que figure en los trabajos preparatorios, permiten llegar a la conclusión que México hacer valer de ese argumento". ${ }^{50}$

Pero si la corte, como vimos, señala que el cumplimiento del artículo 36 se vería reforzado si la obligación del párrafo 1 (b) se proporcionara paralelamente a la lectura de los llamados "Derechos Miranda", que no son otra cosa que garantías del debido proceso legal, podemos afirmar que la pregunta en torno a la naturaleza del derecho reconocido por el artículo 36, párrafo 1 (b) al tiempo que la corte exhorta a Estados Unidos de América a adicionar un derecho a los "Derechos Miranda", pierde relevancia como tal, pues precisamente, por cuanto dijo la corte, se alcanzó el objetivo de considerar este derecho como un derecho esencial en el marco del debido proceso legal.

\section{b. El sentido de la expresión "sin dilación"}

La corte pasa entonces a interpretar el sentido de la expresión "sin dilación”, contenido en el inciso (b) del párrafo 1 del artículo 36. Cabe recordar que la corte no tuvo que pronunciarse sobre este tema en el caso LaGrand y que las partes en el litigio sostuvieron posturas diametralmente opuestas sobre el particular. México consideró que con el propósito de hacer posible una verdadera asistencia consular, y apoyándose en los trabajos preparatorios de la Convención de Viena, la notificación debía ser inmediata, o cuando menos antes de que el acusado rindiera su primera declaración. Estados Unidos de América, en cambio, era de la opinión de que la notificación debe darse apenas sea razonablemente posible hacer- 
lo, tomando en cuenta las circunstancias, y sin que exista retardo deliberado. La corte no encontró respuesta con base en los métodos ordinarios de interpretación que dicta la Convención de Viena sobre el Derecho de los Tratados; en particular, no la halló en los trabajos preparatorios de la Convención de Viena, ante las divergencias que la cuestión suscitó entre los negociadores. La corte concluye que:

La expresión "sin dilación"... no debe entenderse necesariamente como sinónimo de "inmediatamente" después de la detención, existe sin embargo un deber, a cargo de las autoridades que realizan la detención, de brindar dicha información a una persona detenida tan pronto como se percate de que dicha persona es un nacional extranjero, o una vez que existen razones para creer que dicha persona es probablemente un nacional extranjero. ${ }^{51}$

Esta determinación, no cabe duda, habrá de facilitar la labor de protección consular de México y debería servir para guiar los esfuerzos de todos los Estados parte en la Convención de Viena para mejorar la aplicación de las obligaciones del artículo 36.

\section{c. La regla de la preclusión procesal}

Acto seguido, la corte examina la cuestión de la violación del artículo 36, párrafo 2, en tanto que Estados Unidos de América no permitió una revisión y reconsideración verdadera y efectiva de los veredictos de culpabilidad y de las penas afectadas por una violación al artículo 36, párrafo 1.52

51 Ibidem, párr. 88 (trad. del autor).

52 El artículo 36, en su párrafo segundo, dispone que: "Las prerrogativas a las que se refiere el párrafo 1 de este artículo se ejercerán con arreglo a las leyes y reglamentos del Estado receptor, debiendo entenderse, sin embargo, que dichas leyes y reglamentos no impedirán que tengan pleno efecto los derechos reconocidos por este artículo". México alegó en particular que los Estados Unidos de América se apoyan sobre varias doctrinas legales internas para evitar que las violaciones al artículo 36 tengan consecuencias jurídicas. Primero, a pesar del claro análisis realizado por la corte en el caso LaGrand, los tribunales de los Estados Unidos de América, tanto a nivel estatal como federal, continúan invocando la regla de la preclusión procesal para impedir cualquier revisión de violaciones al artículo 36, aún cuando el nacional no tuvo conocimiento de sus derechos de notificación y de comunicación consular, y por consecuencia se vio sin posibilidad de invocar esta violación en proceso porque las autoridades competentes no respetaron lo dispuesto en el artículo 36. A este argumento, Estados Unidos de América respondió que los sistemas de justicia penal de los Estados Unidos de América permiten el examen de todos los errores cometidos en el proceso, 
La corte recordó que la regla de la preclusión procesal exige que sean agotados los recursos a nivel estatal y antes de que pueda interponerse una moción de habeas corpus ante los tribunales federales. Sobre estas bases, la corte concluyó que:

La regla de la preclusión procesal impidió a los abogados de los LaGrand impugnar de manera eficaz, sobre bases distintas al derecho constitucional de los Estados Unidos de América, sus veredictos de culpabilidad y sus penas (ibidem, párr. 91). Esta conclusión de la corte parece ser igualmente válida en relación al presente caso, en el que varios nacionales mexicanos se han encontrado exactamente en la misma situación. ${ }^{53}$

No obstante la contundencia de esta declaración, la corte hace una distinción entre los casos de los individuos que han agotado todos los recursos de la jurisdicción interna para obtener la revisión judicial de los veredictos de culpabilidad y de las penas, y aquellos que, merced a la reparación que dicte la corte, puedan todavía conseguirla. ${ }^{54}$ En cuanto a los primeros, la corte declara que Estados Unidos de América violó las obligaciones que se derivan del artículo 36, párrafo 2 , mientras que respecto de los segundos, la CIJ consideró que sería prematuro concluir que se configuró la misma violación.

Caben dos tipos de interpretación frente a la manera en que procedió la corte ante las violaciones del artículo 36, párrafo 2.

Por una parte, es dable pensar que, ante 48 casos en los que teóricamente los tribunales competentes todavía podrían revisar y reconsiderar los veredictos de culpabilidad y las penas, la corte quiso dar a Estados

utilizando para esto, tanto el procedimiento judicial como el recurso a la clemencia ante el Ejecutivo, descansando en este último, cuando la regla de la preclusión procesal no permite recurrir al primero.

53 Avena, Judgment, op. cit., nota 11, párr. 112 (trad. del autor).

54 En el párrafo 113 de su fallo, la corte dijo que: "En este supuesto, la aplicación de la regla de la preclusión procesal habría tenido el efecto de impedir el pleno efecto de los objetivos que se pretende alcanzar mediante el otorgamiento de los derechos que se señalan en este artículo", y por lo tanto, viola el párrafo 2 del artículo 36. La corte hace notar, adicionalmente, que en diversos de los casos citados en las conclusiones finales de México, la regla de la preclusión procesal ha sido ya aplicada, y que en otros podría ser aplicada en etapas posteriores del proceso. Sin embargo, en ninguno de los casos — salvo en los tres mencionados en el numeral 114 a continuación- los procesos penales contra los mexicanos involucrados han llegado a una fase en la que no exista posibilidad alguna adicional de recurso judicial; es decir, aún no se ha excluido la posibilidad de "revisar y reconsiderar" los veredictos de culpabilidad y las penas, como lo requería la corte en el caso LaGrand, y como se explica más adelante en los numerales 128 y ss. Por lo tanto, sería prematuro que la corte concluyera en este momento que, en esos casos, existe ya una violación a las obligaciones señaladas en el artículo 36, párrafo 2, de la Convención de Viena", Idem. 
Unidos de América la oportunidad de volver las cosas al status quo ante, con base en los criterios de la reparación que definiría más adelante.

Por la otra, teniendo en cuenta los reiterados argumentos de Estados Unidos de América respecto de la inaceptable intromisión que el fallo tendría en su sistema de administración de justicia, la corte no quiso poner a Estados Unidos de América frente a una situación en la que sólo cupiera la conmutación de la pena de muerte por una pena privativa de la libertad en relación con la totalidad de los casos listados en la demanda de México. Tendremos oportunidad de volver sobre este asunto cuando examinemos las consecuencias jurídicas de las violaciones del artículo 36, es decir la cuestión de la reparación.

Al final:

La corte hace notar que en el caso de tres nacionales mexicanos, el sr. Fierro (caso núm. 31), el sr. Moreno (caso núm. 39) y el sr. Torres (caso núm. 53), los veredictos de culpabilidad y las penas son ya definitivos. Incluso, en el caso del sr. Torres, el Tribunal Penal de Apelaciones de Oklahoma ya ha señalado una fecha de ejecución (véase numeral 21 que antecede, in fine). La corte por lo tanto, debe concluir que, en relación a estos tres individuos, los Estados Unidos de América han violando las obligaciones que les corresponden conforme al artículo 36, párrafo 2 de la Convención de Viena. ${ }^{55}$

\section{Las consecuencias jurídicas de las violaciones del artículo 36 de la Convención de Viena. La cuestión de la reparación}

Cuando se hace una comparación entre los tres casos incoados ante la Corte Internacional de Justicia, que se refieren a la aplicación y la interpretación de la Convención de Viena sobre Relaciones Consulares -Breard, LaGrand y Avena-, los puntos en común son evidentes: mismos hechos, mismo Estado responsable, mismos argumentos invocados por las partes, grosso modo misma respuesta de parte de la corte. La diferencia, sin embargo, es palpable.

Mientras que en Breard y LaGrand, los individuos habían sido ejecutados antes de que la corte pudiera ordenar la reparación que se impone en derecho internacional, lo que había llevado a la corte a señalar un tipo 
de reparación prospectiva para el caso de que se repitieran violaciones del artículo 36, en Avena, gracias al respeto de las medidas provisionales ordenadas, los 52 condenados permanecieron y permanecen en vida. Este solo hecho exigía que México buscase la reparación más amplia posible, con base en el derecho de la responsabilidad internacional del Estado.

Partiendo del principio de que las violaciones del artículo 36 tuvieron como efecto viciar de origen los procedimientos por los que fueron sentenciados los 52 mexicanos, y afectaron gravemente las garantías del debido proceso legal, la solicitud en materia de reparación no podía ser otra que la que dicta el derecho internacional, a saber: la reparación debe, en la medida de lo posible, borrar todas las consecuencias del acto ilícito y restablecer el estado que hubiese probablemente existido si dicho acto ilícito no hubiese sido cometido, como dijo en 1928 la Corte Permanente de Justicia Internacional en el caso de la Fábrica de Chorzow.

En última instancia, si México había acudido ante la corte era porque la reparación indicada en el caso LaGrand, o cuando menos la interpretación que de ella dio Estados Unidos de América, no había permitido, en los casos de los mexicanos condenados a la pena de muerte, que los tribunales de los Estados Unidos de América concedieran algún tipo de remedio de carácter jurídico. Cuando llegaba a reconocer que había existido violación del artículo 36, el gobierno de los Estados Unidos de América se limitaba a presentar disculpas al Estado mexicano, ${ }^{56}$ y esto no en todos los casos, o después del fallo LaGrand, refería el caso a los mecanismos de clemencia ejecutiva, que no son instancias judiciales sino meros trámites administrativos para suplicar la misericordia del gobernante, auténticas reliquias de la institución monárquica en la que el soberano tenía todo poder sobre sus súbditos.

En suma, la restitutio in integrum que pidió México es algo que está dentro de lo materialmente posible y que, teniendo en cuenta el valor de la vida humana, no impone a Estados Unidos de América una carga desproporcionada.

La pregunta que el equipo jurídico de México se planteó a lo largo de los catorce meses que duró la instancia, como un alucinante leitmotiv, fue siempre la misma: ¿estará la corte dispuesta a dar a México más de lo que concedió a Alemania?

56 En LaGrand, la corte destacó que en el caso de violaciones del artículo 36 "an apology is not sufficient"; LaGrand, Judgment, op. cit., nota 7, párr. 123. 
Si no fuera así, ¿cómo evitar que el caso mexicano debilite el precedente sentado por el fallo LaGrand?

Pero, por encima de cualquier otra consideración, ¿qué hacer para no agravar la suerte de los 54 condenados, especialmente la de aquellos que pueden ser ejecutados en cualquier momento?

¿De qué manera defender el derecho a la vida de los 54 condenados, sin que se acreditara la tesis de que el verdadero objeto de la controversia era la institución de la pena capital?

Estos eran los términos del dilema que pesaba sobre la estrategia jurídica que debía ponerse en marcha. Al cabo de discusiones que no estuvieron exentas de tensiones al interior del equipo jurídico mexicano, llegamos a acordar que el objetivo debía ser construir una argumentación que, partiendo del acquis del caso LaGrand, fuera llevando a la corte a precisar su interpretación anterior, tomando en cuenta la forma en la que Estados Unidos de América ajustó (o mejor dicho, no ajustó) su comportamiento, e identificara los elementos esenciales de la reparación debida cuando se configuran violaciones del artículo 36 de la Convención de Viena.

Para cualquiera que conozca aunque sea medianamente la jurisprudencia de la corte, es claro que el máximo tribunal internacional no suele cambiar sus criterios en forma radical, especialmente cuando tales criterios son recientes y cuando versan sobre asuntos en los que los aspectos de invasión en la esfera que pertenece a la jurisdicción interna, pesan tanto en el ánimo de una de las partes.

No debe sorprender, entonces, que conforme avanzó el procedimiento, se fueron afinando algunas de las solicitudes que hacía México a la corte, especialmente a la luz de la argumentación de Estados Unidos de América.

En su forma final, las solicitudes de México, tal como fueron leídas por su agente al término de la serie de audiencias sobre el fondo, el 19 de diciembre de 2003, quedaron como sigue:

El gobierno de México respetuosamente solicita que la corte diga y falle que:

1. Los Estados Unidos, al detener, arrestar, enjuiciar, declarar culpables y condenar a los 52 nacionales mexicanos que se encuentran en la antesala de la muerte y que se señalan en la Demanda de México y en la Memoria de México, violaron sus obligaciones jurídicas internacionales para con México directamente y en el ejercicio del derecho que tiene éste de asegu- 
rar la protección diplomática de sus nacionales, al omitir informar, sin dilación, a los 52 nacionales mexicanos, después de su detención, del derecho a la notificación y al acceso a las autoridades consulares conforme a lo dispuesto en el artículo 36(1)(b) de la Convención de Viena sobre Relaciones Consulares; y que privaron a México de su derecho a brindar protección consular y el derecho de los 52 nacionales mexicanos a beneficiarse de la protección que México les hubiera brindado conforme al artículo 36(1)(a) y (c) de la convención;

2. La obligación enunciada en el artículo 36 párrafo 1 de la Convención de Viena, exige que la notificación consular sea efectuada y que una posibilidad razonable de acceso a las autoridades consulares sea otorgada antes de que las autoridades competentes del Estado receptor tomen cualquier medida susceptible de afectar los derechos del nacional extranjero;

3. Los Estados Unidos de América violaron sus obligaciones conforme al artículo 36 párrafo 2 de la Convención de Viena, al no permitir una revisión y una reconsideración verdaderas y efectivas de los veredictos de culpabilidad y de las penas viciadas por la violación a los derechos establecidos en el artículo 36 párrafo 1, al sustituir esa revisión y reconsideración por el recurso a la clemencia y al aplicar la doctrina de la preclusión procesal y otras doctrinas de derecho interno que no reconocen consecuencias jurídicas a la violación del artículo 36 párrafo 1, como tal;

4. En atención a los daños sufridos por México tanto en su propio derecho como en el ejercicio de la protección diplomática a favor de sus nacionales, México tiene derecho a una reparación plena de dichos daños bajo la forma de la restitutio in integrum;

5. Esta restitución consiste en la obligación de reestablecer el status quo ante mediante la anulación o de alguna otra forma que prive de todo efecto o valor los veredictos de culpabilidad pronunciados y las penas dictadas en contra de los cincuenta y dos nacionales mexicanos;

6. Esta restitución incluye de igual forma la obligación de tomar todas las medidas necesarias para asegurar que una violación anterior a los derechos del artículo 36, no tenga incidencia en los procedimientos ulteriores;

7. En la medida en que los cincuenta y dos veredictos de culpabilidad o las penas no fuesen anulados, los Estados Unidos deberán asegurar, por los medios de su elección, una revisión y una reconsideración verdaderas y efectivas de esos veredictos y penas, y esta obligación no podrá ser satisfecha mediante los procedimientos de la clemencia, ni por la aplicación de cualquier regla o doctrina de derecho interno incompatible con el numeral 3) que antecede; $y$

8. Los Estados Unidos de América deberán cesar sus violaciones a los derechos del artículo 36 de la Convención de Viena con respecto a México y sus 52 nacionales, y deberán brindar seguridades y garantías adecuadas 
de que adoptarán medidas suficientes para hacer que se respete de manera acrecentada lo dispuesto en el artículo 36 párrafo 1, y para asegurar el respecto de lo dispuesto en el artículo 36 párrafo $2 .{ }^{57}$

La argumentación en torno a la petición de reparación formulada por México constituyó sin duda alguna la parte más compleja del alegato, toda vez que tenía que fundarse en el derecho de la responsabilidad internacional del Estado, por supuesto, pero también en derecho constitucional y penal de los Estados Unidos de América. No es posible en el marco de este ensayo reproducir la riqueza de la argumentación de México, por lo que se remite al lector a los alegatos del profesor Pierre-Marie Dupuy y del abogado Donald F. Donovan el 15 y el 18 de diciembre de 2003. Asimismo, el lector podrá consultar la argumentación del abogado Stephen Mathias en el alegato que hizo ante la corte el 16 y el 19 de diciembre de 2003.

La mayor dificultad estribaba en conseguir un delicado equilibrio entre lo que se pedía y lo que la corte ya había determinado en el caso LaGrand en el que dejó a Estados Unidos de América la libertad de medios para llevar a cabo la revisión y la reconsideración de los veredictos de culpabilidad y de las penas. Además, Estados Unidos de América había argumentado que la revisión y reconsideración ordenada por la corte constituye una obligación de medios, mas no de resultado.

Será suficiente con indicar que, con fundamento en la jurisprudencia de la Corte Interamericana de Derechos Humanos y de la Corte Europea de Derechos Humanos, así como en numerosos laudos arbitrales, se buscó demostrar que el restablecimiento del status quo ante bien puede traducirse en la anulación de un acto judicial interno. Al efecto, México invocó el reciente caso de la orden de aprehensión en el que la corte ordenó a Bélgica anular la orden de aprehensión librada en contra del ministro de Asuntos Extranjeros de la República Democrática del Congo por ser violatoria de la inmunidad de jurisdicción del afectado. ${ }^{58}$

En este orden, revestía especial importancia el alegato en torno a la falta de idoneidad de los mecanismos de clemencia ejecutiva para cum-

57 Avena, Judgment, op. cit., nota 11, párr. 14 (trad. del autor).

58 Arrest Warrant of 11 April 2000 (Democratic Republic of the Congo v. Belgium), ICJ Reports 2002, http://www.icj-cij.org/. 
plir con el criterio de la corte, así como el argumento del artículo 36 en el marco de las garantías del debido proceso legal..$^{59}$

Al iniciar el análisis de las consecuencias jurídicas de las violaciones, la corte reconoce, sin aparente dificultad, que:

El principio general aplicable a las consecuencias jurídicas de la comisión de un acto internacionalmente ilícito fue declarado por la Corte Permanente de Justicia Internacional en el Caso de la Fábrica de Chorzow de la siguiente manera: "Es un principio de derecho internacional que el incumplimiento de un compromiso conlleva la obligación de repararlo en forma adecuada" (Factory at Chorzow, Jurisdition, 1927, PCIJ, series A, núm. 9, p. 21). En cuanto a la cuestión de saber qué es lo que constituye una "reparación en forma adecuada", ello depende en particular de las circunstancias concretas que rodean cada caso, y de la naturaleza e importancia exactos del daño, en virtud de que se trata de determinar que es una "reparación en forma adecuada" que corresponda al daño causado. ${ }^{60}$

Sin embargo, en la identificación de los elementos constitutivos de la "reparación en forma adecuada", la corte señala que Estados Unidos de América tiene la obligación de "permitir la revisión y reconsideración de los casos de estos nacionales por los tribunales de los Estados Unidos..., con vistas a determinar si en cada caso, la violación al artículo 36 cometida por las autoridades competentes causó en efecto perjuicio al interesado en el transcurso de la administración de justicia penal". ${ }^{61}$

Seguidamente, la corte aclara que los veredictos de culpabilidad y las penas no pueden, como tales, ser considerados contrarios al derecho internacional, sino sólo ciertos incumplimientos de obligaciones convencionales que precedieron tales veredictos y penas. Por ende, la corte no puede aceptar las solicitudes contenidas en los numerales 4 y 5 de las peticiones finales de México. En este contexto, la corte resalta que la anulación parcial o total de los veredictos de culpabilidad y de las penas no es el único medio de reparación, y que el caso Avena debe ser distinguido del caso de la orden de aprehensión. En este último caso, se trataba de la

59 Al respecto, se recomienda la lectura del alegato de la abogada Sandra Babcock, coordinadora del Programa de Asistencia Jurídica a Mexicanos que enfrentan la Pena de Muerte, del gobierno de México, y la del maestro Carlos Bernal, presidente de la Comisión de Derecho Internacional de la Barra Mexicana, Colegio de Abogados, del 15 de diciembre de 2003.

60 Avena, Judgment, op. cit., nota 11, párr. 119 (trad. del autor).

61 Ibidem, párr. 121 (trad. del autor). 
licitud en derecho internacional de la emisión misma por las autoridades belgas de la orden de aprehensión en contra del ministro congolés de Asuntos Extranjeros, respecto de la cual la corte había concluido que era en sí violatoria del derecho internacional.

La corte parece aquí incurrir en un lamentable retroceso en relación con el fallo LaGrand. En efecto, en esa ocasión la corte había señalado que la cuestión de saber cuán útil o eficaz habría resultado la intervención del cónsul o si este último habría proporcionado su asistencia, es a todas luces irrelevante para los efectos del caso.

Basta que la Convención de Viena otorgara tales derechos y que los interesados y el Estado de su nacionalidad se hallasen visto impedidos de recibir y de proporcionar la asistencia consular, según el caso, para que se configure la violación del artículo 36 y se pueda invocar la responsabilidad internacional de Estado. ${ }^{62}$

Esta línea de argumentación se acercaba al reconocimiento del artículo 36 como un derecho humano, o cuando menos como parte esencial de las garantías del debido proceso legal, de la que podía inferirse que la trasgresión de este derecho tiene el efecto de viciar los procedimientos que se lleven a cabo de manera subsecuente y llama a la anulación de lo actuado. En LaGrand, sin embargo, la corte no tenía motivo para conceder una reparación que Alemania, por evidente razón, ya no estaba en condiciones de solicitar. En aquella instancia, la parte más sustantiva de la argumentación giró en torno a la cuestión de la obligatoriedad de las medidas provisionales que Estados Unidos de América no había respetado.

62 En LaGrand, la corte hizo el siguiente razonamiento: "Article 36, paragraph 1, establishes an interrelated régime designed to facilitate the implementation of the system of consular protection. It begins with the basic principle governing consular protection: the right of communication and access (artículo 36, para. $1(a)$ ). This clause is followed by the provision which spells out the modalities of consular notification (artículo 36, para. 1 (b)). Finally Article 36, paragraph 1 (c), sets out the measures consular officers may take in rendering consular assistance to their nationals in the custody of the receiving State. It follows that when the sending State is unaware of the detention of its nationals due to the failure of the receiving State to provide the requisite consular notification without delay, which was true in the present case during the period between 1982 and 1992, the sending State has been prevented for all practical purposes from exercising its rights under Article 36, paragraph 1. It is immaterial for the purposes of the present case whether the LaGrands would have sought consular assistance from Germany, whether Germany would have rendered such assistance, or whether a different verdict would have been rendered. It is sufficient that the Convention conferred these rights, and that Germany and the LaGrands were in effect prevented by the breach of the United States from exercising them, had they so chosen.", LaGrand, Judgment, op. cit., nota 7, párr. 74 . 
A mayor abundamiento, la Comisión de Derecho Internacional, en su comentario al artículo 35 de su Proyecto de Artículos sobre la Responsabilidad del Estado por Hechos internacionalmente Ilícitos, subraya que la restitución jurídica bien puede significar la anulación de una resolución judicial adoptada de manera ilícita en relación con la persona de un extranjero. ${ }^{63}$

En cambio, en nuestro caso, la corte pudo haber extraído todas las consecuencias jurídicas del razonamiento realizado en el caso LaGrand y ordenar una reparación que dejara menos margen de discrecionalidad al Estado responsable y, por consiguiente, menor probabilidad de que se susciten nuevas controversias en torno a las violaciones del artículo 36.

En efecto, como señala el juez ad hoc Sepúlveda en su opinión individual:

Es necesario definir la naturaleza de las obligaciones impuestas por el concepto "por los medios de su elección". Si el punto no es adecuadamente aclarado por parte de la corte, ninguna de las dos partes en el presente caso tendrá una guía jurídica sólida sobre las medidas adecuadas que deben tomarse para encontrar la reparación demandada por México y para cumplir con el recurso ordenado por parte de la corte para liberar a los Estados Unidos de América de su responsabilidad... Para disipar cualquier posible malentendido, existe un precedente que aporta una pauta y que puede ser invocado para asegurar una definición clara. La Corte Permanente de Justicia Internacional decidió que es necesario: "asegurar el reconocimiento legal de una situación, de una vez por todas y con fuerza obligatoria entre las partes, a fin de que la postura legal que quede establecida, no pueda ser otra vez cuestionada en lo que hace a los efectos jurídicos que se deriven de ello" (Interpretation of Judgments, núms. 7 y 8

63 "La expresión "restitución jurídica" se utiliza a veces en los casos en que la restitución requiere o implica la modificación de una situación jurídica, bien en el marco del ordenamiento jurídico del Estado responsable, bien en el marco de sus relaciones jurídicas con el Estado lesionado. Esos casos comprenden la revocación, la anulación o la enmienda de una disposición constitucional o legislativa promulgada en violación de una norma de derecho internacional, la anulación o revisión de un acto administrativo o de una resolución judicial ilícitamente adoptados con respecto a la persona o a los bienes de un extranjero o la exigencia de que se adopten disposiciones (en la medida en que el derecho internacional lo autorice) para dar por terminado un tratado", Informe de la Comisión de Derecho Internacional, 53 periodo de sesiones, Documentos oficiales de la Asamblea General, A/56/10, p. 255. 
—Factory at Chorzów_, Judgment, núm. 11, 1927, PCIJ, serie A, núm. 13, p. 20). ${ }^{64}$

Este punto de vista, con el que coincidimos plenamente, tiene mayor importancia a la luz del párrafo 151 del fallo, en el que la corte declara que sus conclusiones se aplican por igual a los casos de otros nacionales extranjeros que se encuentren en los Estados Unidos de América, en vista de las cuestiones de principio que plantea el fallo en relación con la aplicación de la Convención de Viena. En otras palabras, la sentencia tiene efectos también frente a terceros Estados parte en la Convención de Viena, por más que sus consecuencias jurídicas se limiten a las partes en la controversia, conforme al artículo 59 del Estatuto de la Corte. ${ }^{65}$

Al hacer esta aclaración, la corte está conciente de la importancia de los criterios que definió en el fallo y se propone que beneficien a todos, con vistas a facilitar la implementación del sistema de protección consular que consagra la Convención de Viena.

Sin duda, en Avena la corte no aporta demasiado a la consolidación del régimen de la responsabilidad del Estado afanosamente codificado por la Comisión de Derecho Internacional después de cinco décadas de trabajos. Antes, parece crear un régimen subsidiario de la responsabilidad que lejos de contribuir a la universalidad del derecho internacional, acaso genera más fragmentación.

No obstante lo anterior, la corte consigue satisfacer las demás solicitudes de México al precisar, como no tuvo ocasión de hacerlo en LaGrand, los medios por los que debe ser reparado el daño que Estados unidos causó a México y a sus nacionales, tomando como punto de partida la solicitud contenida en el numeral 7 de sus peticiones finales.

64 Avena, Judgment, op. cit., nota 11, Separate Opinion of Judge ad hoc Sepúlveda, párr. 67. En el párrafo 68 de su opinión, el juez ad hoc Sepúlveda señala también que: "Las medidas de reparación deben determinar la forma en la que las leyes y reglamentos de los Estados Unidos, introduciendo un elemento de efectividad que tiene que ser forzoso y obligatorio, 'que dichas leyes y reglamentos no impedirán que tengan pleno efecto los derechos reconocidos por este artículo'. La revisión y reconsideración del veredicto y de la pena deben tomar en cuenta el incumplimiento a los derechos establecidos en la convención. Estos derechos deben ser considerados como pertenecientes a la categoría de derechos fundamentales que interfieren en el debido proceso legal. Si se otorga pleno efecto a los propósitos de dichos derechos, y si la revisión y reconsideración toman en cuenta la naturaleza de la violación a los derechos, entonces el margen en la aplicación del principio que postula 'por los medios de su propia elección' se vuelve más estrecho. Los medios deben ser eficaces y la elección debe ser muy selectiva" (trad. del autor).

65 "La decisión de la corte no es obligatoria sino para las partes en litigio y respecto del caso que ha sido decidido". 
La corte, sin negar la libertad de medios que señaló para llevar a cabo la revisión y la reconsideración, indica que ésta conlleva una restricción; "debe llevarse a cabo 'tomando en cuenta la violación a los derechos señalados en la convención' (ICJ, Reports 2001, párr. 125), incluyendo en particular, la cuestión de las consecuencias jurídicas que esa violación ha tenido en el seguimiento del proceso penal". ${ }^{66}$ En este sentido, la CIJ reconoce que la regla de la preclusión procesal, tal y como es aplicada, impide al interesado hacer valer sus derechos al amparo de la Convención de Viena y lo reduce a buscar reparación en la Constitución de los Estados Unidos de América.

En este punto, la corte se distancia del argumento según el cual los derechos del artículo 36 no representan valor agregado alguno en relación con las garantías procesales de la Constitución de Estados Unidos de América. Se trata de obligaciones convencionales que, independientemente de su caracterización y cualesquiera que sean los derechos de la defensa previstos en el derecho constitucional estadounidense, deben ser respetadas por Estados Unidos de América y que constituyen, como dijo en LaGrand, un régimen interrelacionado diseñado para facilitar la implementación del sistema de protección consular. ${ }^{67}$

La corte pasa a examinar la cuestión de saber si la obligación de revisar y reconsiderar puede ser o no satisfecha por los procedimientos de la clemencia ejecutiva.

En primer término, la corte establece que, para que la revisión y la reconsideración sean efectivas, debe tomar en cuenta la violación de los derechos previstos en la Convención de Viena, es decir que deberá sopesarse tanto la violación como tal de los derechos del artículo 36, como el perjuicio que resulte, y que este ejercicio debe abarcar tanto el veredicto de culpabilidad, como la pena impuesta.

Por consiguiente, "es crucial en el procedimiento de revisión y de reconsideración la existencia de un procedimiento que garantice que se dé todo el peso debido a la violación de los derechos establecidos en la Convención de Viena, independientemente del resultado de dichas revisión y reconsideración". ${ }^{6}$ 
Debe destacarse, en este punto del razonamiento de la corte, en el que el máximo tribunal va más allá de lo dicho en LaGrand, el equilibrio logrado entre el requisito de que se compruebe la existencia del perjuicio como resultado de la violación del artículo 36 y la exigencia de que la revisión y reconsideración abarque tanto el veredicto como la pena, "dando todo el peso debido, accorder tout le poids voulu, full weight to be given" a esta violación. Este aspecto del fallo se reproduce en el párrafo 11 del dispositivo y con él la corte quiso, sin duda alguna, no permitir que se ponga en entredicho la importancia que asigna a la violación como tal del artículo 36. Si se lee este dictum a la luz del pronunciamiento sobre la vinculación con los "Derechos Miranda", que ya comentamos, la cuestión de la caracterización de los derechos del artículo 36 como derecho humano es ya de poca monta.

La corte concluye que el procedimiento judicial es el idóneo para este propósito y aclara que así lo había entendido en el caso LaGrand. ${ }^{69}$ En efecto, de lo que se trata es que el recurso a la clemencia, tal y como se practica en Estados Unidos de América, "no parece satisfacer por sí sola a las exigencias descritas en el párrafo 138 supra y por ende, no puede por sí misma constituir un medio adecuado de revisión y reconsideración". ${ }^{70}$

Lo dicho por la corte en este apartado reviste tal importancia desde el punto de vista de la reparación que, en los párrafos 9 y 11 del dispositivo, el fallo hace expresamente alusión a los criterios definidos en los párrafos 138 a 141 del cuerpo de la sentencia.

De esta manera, México obtuvo algo absolutamente esencial para la defensa de los condenados a la pena de muerte: independientemente del resultado de la revisión y reconsideración, ésta solo puede intervenir en el marco del procedimiento judicial global por el cual se ha juzgado al condenado.

En otras palabras, se ha restaurado plenamente la posibilidad de hacer valer las violaciones del artículo 36 y de volver las cosas al status quo ante, si así resultase de la revisión y reconsideración del veredicto de culpabilidad pronunciado y de la pena impuesta, acorde con los criterios definidos en el fallo. 
Ahora bien, la corte deja abierta una rendija para que la clemencia pueda, en un momento dado, "completar la revisión y reconsideración judiciales". ${ }^{71}$ Nótese que no permite la corte que se sustituya la revisión y reconsideración judiciales por el mecanismo de la clemencia, pero le asigna un papel, digamos residual o subsidiario, pues "en esta medida... los procedimientos de clemencia tienen cierta eficacia para salvar la vida de los condenados que se hallan en el corredor de la muerte" 72 y cita los tres casos de los mexicanos a que se refiere en su párrafo 114. Se trata de aquellos condenados (Fierro, Torres y Moreno Ramos) que, habiendo agotado los recursos internos, pueden esperar que el recurso de la clemencia los libre de una muerte cierta y tengan luego oportunidad de buscar la revisión y reconsideración de sus veredictos.

Sin decirlo, la corte estableció, de manera indirecta, una suerte de relación entre la determinación de violaciones al artículo 36, párrafo 2 y la conmutación de la pena, como la reparación adecuada cuando se han agotado los recursos de la jurisdicción interna, sin perjuicio de la revisión y reconsideración del veredicto de culpabilidad.

Por último, debe subrayarse que, con el efecto hacia terceros que desea imprimir la corte a su decisión como quedó reflejado en el párrafo 151 del fallo, el máximo tribunal quiso también indicar que con el caso Avena se cierra la trilogía de este tipo de contenciosos. Esperémoslo.

\section{El FALLO AVENA ANTE LA PRUEBA DE LOS HECHOS}

\section{Osbaldo Torres}

Como señalamos, tres semanas antes de que la corte rindiera su fallo, las autoridades judiciales de Oklahoma fijaron fecha de ejecución a Osbaldo Torres para el 18 de mayo de 2004, algo que México denunció en su momento como violatorio de la ordenanza sobre las medidas provisionales. La corte expresó en el fallo su preocupación por esta circunstancia, ${ }^{73}$ pero indicó que, a partir de la fecha del fallo, las obligaciones a

71 Idem.

72 Idem.

73 "La corte hace constar que a la fecha de este fallo, estas tres personas no han sido ejecutadas, pero advierte con preocupación que mediante una Resolución de fecha 1o. de marzo del 2004, la Corte Penal de Apelaciones de Oklahoma ha señalado como fecha de ejecución del señor Torres, el 18 de mayo de 2004”, Avena, Judgment, op. cit., nota 11, párr. 21 (trad. del autor). 
cargo de Estados Unidos de América contenidas en la ordenanza sobre las medidas provisionales, quedaban sustituidas por las medidas contempladas en el fallo y subrayó que, en el caso de las tres personas que fueron beneficiadas por las medidas provisionales, "corresponde a los Estados Unidos de América encontrar un recurso de reparación adecuado, de la misma naturaleza que el de la revisión y la reconsideración, conforme al criterio que se señaló en los numerales 138 y siguientes del presente fallo". 74

El 13 de mayo de 2004 la Corte de Apelaciones Criminales del Estado de Oklahoma decidió decretar la suspensión indefinida de la ejecución de Osbaldo Torres y ordenó una nueva audiencia al nivel de una corte de distrito para revisar ciertas pruebas aportadas en el procedimiento por el que fue sentenciado a la pena capital y su relación con la falta de asistencia consular. ${ }^{75}$

Al respecto, debe destacarse que unos de los jueces, el juez Chapel, en una opinión concurrente con la mayoría, observó que conforme a la llamada cláusula de supremacía del derecho internacional consignada en el artículo 6 de la Constitución de los Estados Unidos de América, la facultad del gobierno federal para celebrar tratados es independiente y superior a las facultades de los estados federados y comentó que la Corte de Apelaciones está obligada por el tratado y en tal sentido:

We are bound to give full faith and credit to the Avena decision... the State Department has also consistently turned to the International Court of Justice to provide a binding resolution of disputes under the Vienna Convention, and has relied on the binding nature of International Court of Justice decisions to enforce United Status rights under the Convention. The Avena decison mandates a remedy for a particular violation of Torres's, and Mexico's rights under the Vienna Convention. ${ }^{76}$

74 Ibidem, párr. 152.

75 En su decisión, la Corte de Apelaciones pidió a la Corte de Distrito que se abocara a lo siguiente: “(a) Whether Torres was prejudiced by the State's violation of his Vienna Convention rights in failing to inform Torres, after he was detained, that he had the right to contact the Mexican consulate; and (b) ineffective assistance of counsel", Oklahoma Court of Criminal Appeals, Osabaldo Torres $v$. the State of Oklahoma, núm. PCD-04-442, 13 de mayo de 2004, International Law in Brief, developments in international law prepared by the American Society of International Law, 23 de julio de 2004.

76 Idem. 
La decisión de la Corte de Oklahoma responde a la petición de habeas corpus extraordinario que presentaron los defensores del connacional ante dicho tribunal el 30 de abril de 2004.

Mediante el recurso referido, la defensa del señor Torres hizo valer las graves violaciones cometidas en el caso, incluida la violación al artículo 36 de la Convención de Viena sobre Relaciones Consulares por parte de las autoridades de Oklahoma. Asimismo, los abogados hicieron notar a la corte estatal la falta de evidencia que acredite la participación del señor Torres en la comisión material de los delitos que se le imputan y que desembocaron en la imposición de la pena capital.

Por su parte, el gobierno de México intervino ante la Corte de Oklahoma como amicus curiae, con base en el fallo Avena. En su intervención, México exhortó al tribunal de Oklahoma a considerar el recurso de habeas corpus, como un medio de dar cumplimiento a la revisión y reconsideración del caso del señor Torres, ordenadas en el fallo de la Corte Internacional de Justicia.

El mismo día en que la Corte de Apelaciones rindió su decisión ordenando suspender indefinidamente la ejecución, el gobernador de Oklahoma anunció su decisión de conmutar por cadena perpetua la sentencia a muerte de Osbaldo Torres. En su decisión, el gobernador se refirió expresamente a la violación de la Convención de Viena, como uno de los motivos que lo llevó a considerar favorablemente la recomendación de la Junta de Perdones del Estado.

Este caso, siguiendo el precedente del caso de Gerardo Valdez en la misma jurisdicción, pero con el valor agregado del fallo Avena, demuestra la posibilidad material de dar cumplimiento a una decisión de un órgano judicial internacional, sin cancelar del todo (pero sin que se sustituya) la posibilidad de la clemencia cuando se han agotado todos los recursos internos. De no haber concedido el gobernador la conmutación de la pena, podía haber ocurrido que la corte de distrito, sobre la base de lo actuado, revocara la pena y se sentenciara al connacional a una pena distinta. Con la conmutación concedida, queda abierta la posibilidad de que Osbaldo Torres solicite, de cualquier forma, la revisión y reconsideración del veredicto de culpabilidad. 


\section{Rafael Camargo}

El 12 de agosto de 2004, una corte federal del Estado de Oklahoma anunció su decisión de conmutar, por cadena perpetua, la sentencia a muerte que pesaba sobre el connacional Rafael Camargo. Este caso fue incluido en la lista de los mexicanos objeto del litigio de México en la Corte Internacional de Justicia.

En su decisión, la corte federal se refirió al fallo Avena, reconoció que los derechos del artículo 36 habían sido violados por las autoridades del Estado de Arkansas y estimó que la conmutación de la pena capital es un medio de reparación adecuado para subsanar cualquier perjuicio que se hubiera causado por la violación de la Convención de Viena.

En este contexto, los abogados del señor Camargo argumentaron, con el apoyo del gobierno de México, el retraso mental del sentenciado que no pudo ser considerado en el momento adecuado del procedimiento, ante la falta de asistencia consular.

Es muy pronto para poder apreciar el impacto que tendrá el fallo de la corte en los restantes casos de mexicanos sentenciados a la pena de muerte en los Estados Unidos de América. Lo ocurrido hasta ahora con los dos casos referidos, es sin embargo sumamente alentador en cuanto a la posibilidad material de dar cumplimiento a la orden de la corte e ir creando los precedentes necesarios para orientar el criterio de los tribunales. Al mismo tiempo, puede generar, en las jurisdicciones de los Estados Unidos de América, una actitud de mayor proclividad a respetar el derecho internacional. Por los tiempos que corren, no es poca cosa. 